\title{
Reassessing Foraminiferal Stable Isotope Geochemistry: Impact of the Oceanic Carbonate System (Experimental Results)
}

\author{
J. Bijma ${ }^{1 *}$, H.J. Spero ${ }^{2}$ and D.W. Lea ${ }^{3}$ \\ ${ }^{1}$ Universität Bremen, Fachbereich Geowissenschaften, Postfach 3304 40, \\ D-28334 Bremen, Germany \\ ${ }^{2}$ Department of Geology, University of California Davis, Davis, \\ California 95616, U.S.A. \\ ${ }^{3}$ Department of Geological Sciences and the Marine Science Institute, University of \\ California Santa Barbara, Santa Barbara, California 93106, U.S.A. \\ * corresponding author (e-mail): jbijma@uni-bremen.de
}

\begin{abstract}
Laboratory experiments with living planktic foraminifers show that the $\delta^{13} \mathrm{C}$ and $\delta^{18} \mathrm{O}$ values of shell calcite decrease with increasing sea water $\mathrm{pH}$ and/or carbonate ion concentration. The effect has been quantified in symbiotic (Orbulina universa) and non-symbiotic (Globigerina bulloides) species and is independent of symbiont activity and temperature. It is concluded that a kinetic fractionation process affects both the carbon and oxygen isotopic composition of the shell simultaneously. At present it cannot be determined definitively whether the relationship is controlled by the $\mathrm{pH}$ dependent balance between hydration and hydroxylation of $\mathrm{CO}_{2}$ or by $\left[\mathrm{CO}_{3}^{2-}\right]$ related variations in the calcification rate. However, independent of which factor ultimately controls the relationship between the carbonate chemistry and isotopic fractionation, in the real ocean $\left[\mathrm{CO}_{3}^{2-}\right]$ and $\mathrm{pH}$ covary linearly across the relevant $\mathrm{pH}$ range. The true relationship between shell isotopic composition and the bulk carbonate chemistry is masked by the fact that host respiration and symbiont activity locally modify the carbonate system. Respiration lowers and photosynthesis increases ambient $\mathrm{pH}$ and $\left[\mathrm{CO}_{3}^{2-}\right]$. This translates into modified absolute shell values but leaves the slope between the shell isotopic composition and the bulk carbonate chemistry unaffected. A second level of shell isotopic modification is introduced by the incorporation of respired carbon, enriched in ${ }^{12} \mathrm{C}$, which depletes the shell $\delta^{13} \mathrm{C}$ value. In symbiont bearing species this depletion is partially negated by a shell $\delta^{13} \mathrm{C}$ enrichment in the light. As an alternative to the RUBISCO hypothesis (enrichment via preferential removal of ${ }^{12} \mathrm{CO}_{2}$ ), we propose that scavenging of respired $\mathrm{CO}_{2}$ during photosynthesis, raises the shell $\delta^{13} \mathrm{C}$ value. Our results have partly been documented before (Spero et al. 1997) and demonstrate that the carbonate chemistry is undoubtedly a major control on temporal geochemical variability in the fossil record. For instance, the sea water carbonate system of the prePhanerozoic world (Berner 1994; Grotzinger and Kasting 1993) or during glacials (Sanyal et al. 1995) was significantly different from today confounding direct interpretation of foraminiferal stable isotope data using existing relationships (see companion paper in this volume by Lea et al.).
\end{abstract}

\section{Introduction}

Spero et al. (1997) describe a series of experiments demonstrating that planktic foraminiferal $\delta^{18} \mathrm{O}$ and $\delta^{13} \mathrm{C}$ are influenced by sea water carbonate chemistry. In this paper, we describe these experiments in greater detail, discuss previously unpublished experiments and speculate on the potential mechanisms controlling the observed responses.

Based on a theoretical study of the thermodynamic properties of isotopic substances, Urey (1947) proposed that the ${ }^{18} \mathrm{O}$ content of calcium carbon- 
ate could be used as a paleothermometer for the ocean. The method is based on the fact that sea water and calcite differ in their ${ }^{18} \mathrm{O} /{ }^{16} \mathrm{O}$ ratios, when in thermodynamic equilibrium, and that this difference decreases with increasing temperature. McCrea (1950) demonstrated in the laboratory that synthetic calcium carbonate when precipitated in equilibrium with sea water is enriched in ${ }^{18} \mathrm{O}$ relative to sea water but less so with increasing temperature and thus behaves as predicted by Urey. This empirical relationship was the first, so called, paleotemperature relationship. Another milestone were the papers by Epstein et al. $(1951,1953)$ who were the first to show that marine invertebrates grown in the natural environment deposit calcium carbonate in equilibrium with sea water. Many new paleotemperature equations have been developed since this early pioneer work (for a review see Bemis et al. 1998) but the problem in determining the "true" paleotemperature is not only one of choosing the correct equation but, more importantly, one of choosing the correct value for $\delta^{18} \mathrm{O}$ of sea water $\left(\delta^{18} \mathrm{O}_{w}\right)$. For the geologic past, this amounts to knowing paleosalinity and the relationship between salinity and $\delta^{18} \mathrm{O}_{\mathrm{w}}$ (e.g. Berger 1979; Broecker and Van Donk 1970; Fairbanks et al. 1992; Rozanski et al. 1993; Schrag et al. 1996; Shackleton 1967, 1974).

Beyond the glacial ice volume effect and the effect of precipitation/evaporation, so called "vital effects" were recognized. Contrary to Emiliani's (1954) interpretation that the oxygen isotopic differences among planktic foraminifers reflect differences in depth habitat and hence differences in precipitation temperature, Duplessy et al. (1970) argued that the differential oxygen isotopic fractionation in benthic foraminifers from the same level in a core requires a different explanation and they suggested that metabolic $\mathrm{CO}_{2}$ depleted in ${ }^{18} \mathrm{O}$ is incorporated into the shells of benthic and possibly also planktic foraminifers. The hypothesis that planktic foraminifers have different ${ }^{18} \mathrm{O}$-fractionation factors was subsequently confirmed by Shackleton et al. (1973) and later substantiated by numerous other studies (e.g. Curry and Matthews 1981a; Duplessy et al. 1981; Fairbanks et al. 1980; Shackleton 1974; Vergnaud-Grazzini
1976; Williams et al. 1979). For instance, Buchardt and Hansen (1977) note that benthic foraminifers bearing symbiotic algae are depleted in ${ }^{18} \mathrm{O}$ relative to symbiont barren species and Erez (1978b) argues that with greater photosynthetic activity, incorporation of light metabolic $\mathrm{CO}_{2}$ results in anomalously light carbon and oxygen isotopic compositions of hermatypic corals and benthic foraminifers. However, when dealing with differences in $\delta^{18} \mathrm{O}$ through time, vital effects have generally been assumed to be constant (or zero) and were therefore neglected.

The interpretation of the carbon isotopic composition proved to be more complicated than $\delta^{18} \mathrm{O}$. Due to the preferential fixation of ${ }^{12} \mathrm{CO}_{2}$ by primary producers and subsequent transport and decomposition of organic matter below the euphotic zone, surface waters of the ocean are depleted in ${ }^{12} \mathrm{C}$ whereas the deeper ocean is ${ }^{12} \mathrm{C}$-enriched. Thus, as a consequence of community production and respiration, $\delta^{13} \mathrm{C}$ depth profiles are related to the oxygen concentration and inversely correlated with the nutrient concentration (the stoichiometric proportionality constant with $\mathrm{PO}_{4}$ is ca. $0.93 \%$ per mol, $\mathrm{kg}^{-1}$ : Broecker and Peng 1982). Hence the $\delta^{13} \mathrm{C}$ of surface dwelling foraminifers is used as a surface water fertility proxy and the difference in $\delta^{13} \mathrm{C}$ between planktics and benthics $\left(\Delta \delta^{13} \mathrm{C}\right)$ was introduced as a measure of the strength of the biological pump (e.g. Broecker 1971; 1973; 1981). Another source for variation of $\delta^{13} \mathrm{C}$ in dissolved inorganic carbon $\left(\delta^{13} \mathrm{C}_{\Sigma \mathrm{CO} 2}\right)$ is the fractionation between carbon in atmospheric $\mathrm{CO}_{2}$ and the total dissolved $\mathrm{CO}_{2}\left(\mathrm{CCO}_{2}\right)$ in surface ocean water. The ${ }^{13} \mathrm{C} /{ }^{12} \mathrm{C}$ ratio in atmospheric $\mathrm{CO}_{2}$ is on average 9 $\% o$ lower than that in surface ocean $\Sigma \mathrm{CO}_{2}$ and the extent of fractionation depends on temperature (e.g. Broecker and Maier-Reimer 1992; Charles et al. 1993; Lynch-Stieglitz et al. 1995). As a result, high latitude surface water have a higher ${ }^{13} \mathrm{C} /{ }^{12} \mathrm{C}$ ratio than low latitude surface water. Generally, this thermodynamic imprint is not very strong due to very slow isotopic equilibration (Broecker and Peng 1982), however, if there is sufficient time for gas exchange, a significant signal is produced (Charles and Fairbanks 1990). A third source of variation is the so called "Mackensen effect". 
Mackensen et al. (1993) hypothesised that growth and reproduction of benthic foraminifers coincides with the seasonal flux of phytodetritus. Because $\delta^{13} \mathrm{C}$ of freshly accumulated phytodetritus was 3 to $4 \%$ lower than surface sediment organic carbon they argued that $\delta^{13} \mathrm{C}$ of epibenthic shells, formed during remineralisation of this fluffy layer (locally and temporarily depleting $\delta^{13} \mathrm{C}_{\mathrm{\Sigma CO} 2}$ ), is depleted compared to $\delta^{13} \mathrm{C}_{\Sigma \mathrm{CO} 2}$ found throughout the rest of the year.

The main complication associated with the interpretation of $\delta^{13} \mathrm{C}$ records from foraminiferal shells is a prominent vital effect. Already Craig (Revelle and Fairbridge 1957) had shown that the carbon isotopes in foraminiferal shells are precipitated out of equilibrium with $\delta^{13} \mathrm{C}$ of $\Sigma \mathrm{CO}_{2}$ and potentially reflect utilization of metabolic $\mathrm{CO}_{2}$. The large range of disequilibrium precipitation was confirmed by many studies (for a review see e.g. Berger 1979; Duplessy 1978). A milestone for the investigation of vital effects on stable isotopic fractionation was the establishment of culture techniques for planktic foraminifers by the research groups of Allen Bé, Roger Anderson, Christoph Hemleben and Michael Spindler (e.g. Bé 1979; Bé 1980; Bé 1982; Bé and Anderson 1976; Bé et al. 1979; Bé et al. 1977; Hemleben and Spindler 1983; Hemleben et al. 1989; Hemleben et al. 1985; Hemleben et al. 1987; Spindler and Hemleben 1980). Using laboratory cultures, Erez and Luz (1983) derived the first empirical paleotemperature equation for Globigerinoides sacculifer and, for instance, Bouvier-Soumagnac and Duplessy (1985) were able to verify their plankton tow based temperature: $\delta^{18} \mathrm{O}$ relationships. Culture experiments were also imperative to investigate the impact of algal symbiosis on the shell $\delta^{13} \mathrm{C}$ composition of benthic (Erez 1978b; Williams et al. 1981b; Zimmermann et al. 1983) and planktic foraminifers (Spero and DeNiro 1987). In contrast to benthic foraminifers and some corals (Erez 1978b; Land et al. 1977), Spero and Deniro concluded that increased symbiont photosynthetic activity in Orbulina universa, resulted in a ${ }^{13} \mathrm{C}$ enrichment of the shell. Their conclusion was supported by other studies (Cummings and McCarty 1982; Goreau 1977; Weber and Woodhead 1970) and later verified for other species of planktic foraminifers (Bijma et al. 1998; Spero and Lea 1993; Spero et al. 1991). The enrichment was attributed to the preferential removal of ${ }^{12} \mathrm{CO}_{2}$ by the $\mathrm{CO}_{2}$ fixing enzyme ribulose 1,5-biphosphate carboxylase-oxygenase (RUBISCO) during symbiont photosynthesis, enriching the calcifying environment in ${ }^{13} \mathrm{C}$. Host respiration was shown to deplete the shell isotopic composition (e.g. Bijma et al. 1998; Spero and Lea 1996). This observation was explained by the contribution of metabolic $\mathrm{CO}_{2}$, enriched in ${ }^{12} \mathrm{C}$, to the calcifying environment.

During the past four decades, stable oxygen and carbon isotope measurements on biogenic calcite and aragonite (for a review see e.g. Wefer and Berger 1991) have become standard tools for reconstructing paleoceanographic and paleoclimatic change. By assuming that our understanding of the major parameters controlling stable isotope incorporation into biogenic calcite is complete, these geochemical proxies have been used to reconstruct glacial ice volumes(e.g. Fairbanks 1989; Mix 1987), sea surface (SST) and deep water temperatures (e.g. Zahn and Mix 1991), ocean circulation changes (e.g. Boyle 1990; Charles and Fairbanks 1992; Labeyrie et al. 1987) and glacial-interglacial shifts between the terrestrial and oceanic carbon pools (Shackleton 1977). However, the list of factors controlling the stable isotopic compositions of shells is still incomplete. Data from isotopic calibration studies have suggested that an unidentified parameter affects carbon and oxygen isotope ratios in foraminiferal shells (e.g. Duplessy et al. 1981; Fairbanks et al. 1982; Williams et al. 1979). Although shell $\delta^{13} \mathrm{C}$ values may be affected by vital effects, $\delta^{18} \mathrm{O}$ values should be insensitive to physiology. Yet, oxygen isotope data from foraminifers collected in surface plankton tows yield SST reconstructions that are several degrees warmer than measured ocean temperatures (Williams et al. 1981a). Similarly, the covariation of carbon and oxygen isotopes in planktic foraminifers (e.g. Berger et al. 1978; Curry and Matthews 1981a; Curry and Matthews 1981b; Kahn and Williams 1981) cannot be explained by shifting depth habitats during ontogeny. In terms of equilibrium fractionation the trends are opposite to those found 
in the water column. If foraminifers were fractionating in isotopic equilibrium lightest $\delta^{18} \mathrm{O}$ values should be associated with heaviest $\delta^{13} \mathrm{C}$ values. Stable isotope studies on other calcifying organisms such as calcareous algae, hermatypic corals and echinoderms show similar disequilibria (McConnaughey 1989b; Wefer and Berger 1991) suggesting that these proxies are also equivocal and that some environmental or biological parameter(s) in addition to those already identified must be affecting skeletal stable isotope values. Interestingly, laboratory and field data show that skeletal $\delta^{18} \mathrm{O}$ and $\delta^{13} \mathrm{C}$ covary (McConnaughey 1989a; McConnaughey 1989b; Spero et al. 1997; Spero and Lea 1996) suggesting the mechanism that affects shell ${ }^{18} \mathrm{O} /{ }^{16} \mathrm{O}$ ratios also has an effect on ${ }^{13} \mathrm{C} /$ ${ }^{12} \mathrm{C}$.

In this paper we examine the impact of changes in carbonate chemistry on the stable carbon and oxygen isotope composition of a symbiont bearing and a symbiont barren species of planktic foraminifers and subsequently discuss potential equilibrium and kinetic fractionation mechanisms. The implications of the observed isotope effects for paleo-oceanographic and-climatic reconstructions are discussed in the companion paper by Lea et al. (this volume).

Our initial hypothesis was that glacial symbiont bearing foraminifers should be depleted in ${ }^{13} \mathrm{C}$ relative to their Holocene counterparts because dissolved $\mathrm{CO}_{2}$ availability (the $\mathrm{CO}_{2}$ aq concentration) was reduced in the glacial ocean. Since the $\delta^{13} \mathrm{C}$ of algae increases as less $\mathrm{CO}_{2}$ aq is available (Farquhar et al. 1982) and [ $\left.\mathrm{CO}_{2} \mathrm{aq}\right]$ was reduced in the glacial ocean, we predicted that symbiont fractionation and hence ${ }^{13} \mathrm{C}$ enrichment of the calcifying environment was reduced during glacial times. We found that symbiont bearing foraminifers grown at lower $\left[\mathrm{CO}_{2} \mathrm{aq}\right]$ are indeed depleted in ${ }^{13} \mathrm{C}$ but for a different reason than we initially hypothesised.

\section{Material and Methods}

During the summers of 1993 through 1996 culture experiments were conducted at the Wrigley Environmental Science Center on Santa Catalina Island (California) to investigate the influence of sea water carbonate chemistry on the $\delta^{13} \mathrm{C}$ and $\delta^{18} \mathrm{O}$ of the shells of the symbiont bearing planktic foraminifer Orbulina universa (d'Orbigny) and the symbiont barren Globigerina bulloides d'Orbigny.

\section{Orbulina Universa}

Orbulina universa has a tropical to temperate distribution in the euphotic zone. Each adult individual is associated with 3,000 to 7,000 (Spero and Parker 1985) dinoflagellate symbionts (Gymnodinium beii). The symbionts are distributed in a halo around the calcitic shell (cf. Fig.1a). Orbulina universa, like most spinose species, is carnivorous and feeds primarily on calanoid copepods at a rate of one to two per day (Spindler et al. 1984). New chambers are added to the existing trochospire at regular intervals. The transition to the adult stage is marked by the formation of a spherical chamber, a feature that is unique in this species. This terminal chamber is secreted around the thinly calcified trochospiral juvenile shell. At this stage numerous large pores facilitate the migration of the symbionts along the spines. The spherical chamber continues to calcify for a period of 1-7 days (Spero 1988) before spine resorption and gametogenetic (GAM) calcification signal impending gametogenesis. GAM calcification produces $13-28 \%$ of the shell mass over a period of several hours (Bé 1980; Bé et al. 1983; Spero 1986). After gametogenesis the terminal sphere constitutes between 90 to $95 \%$ of the calcite by weight. Frequently the spiral stage is dissolved completely. Reproduction of this species is tuned to the lunar cycle (Bijma et al. 1990).

\section{Globigerina Bulloides}

Globigerina bulloides (Fig. 1b) is a non-symbiotic species that is typically associated with temperate to sub-polar water masses but is also characteristic in lower latitudes upwelling environments (Bé and Hutson 1977; Bé and Tolderlund 1971; Naidu and Malmgren 1996a; 1996b). In these regions, G. bulloides often dominates the flux to the ocean floor (Sautter and Thunell 1989; Sautter and Sancetta 1992) and is therefore an important source 

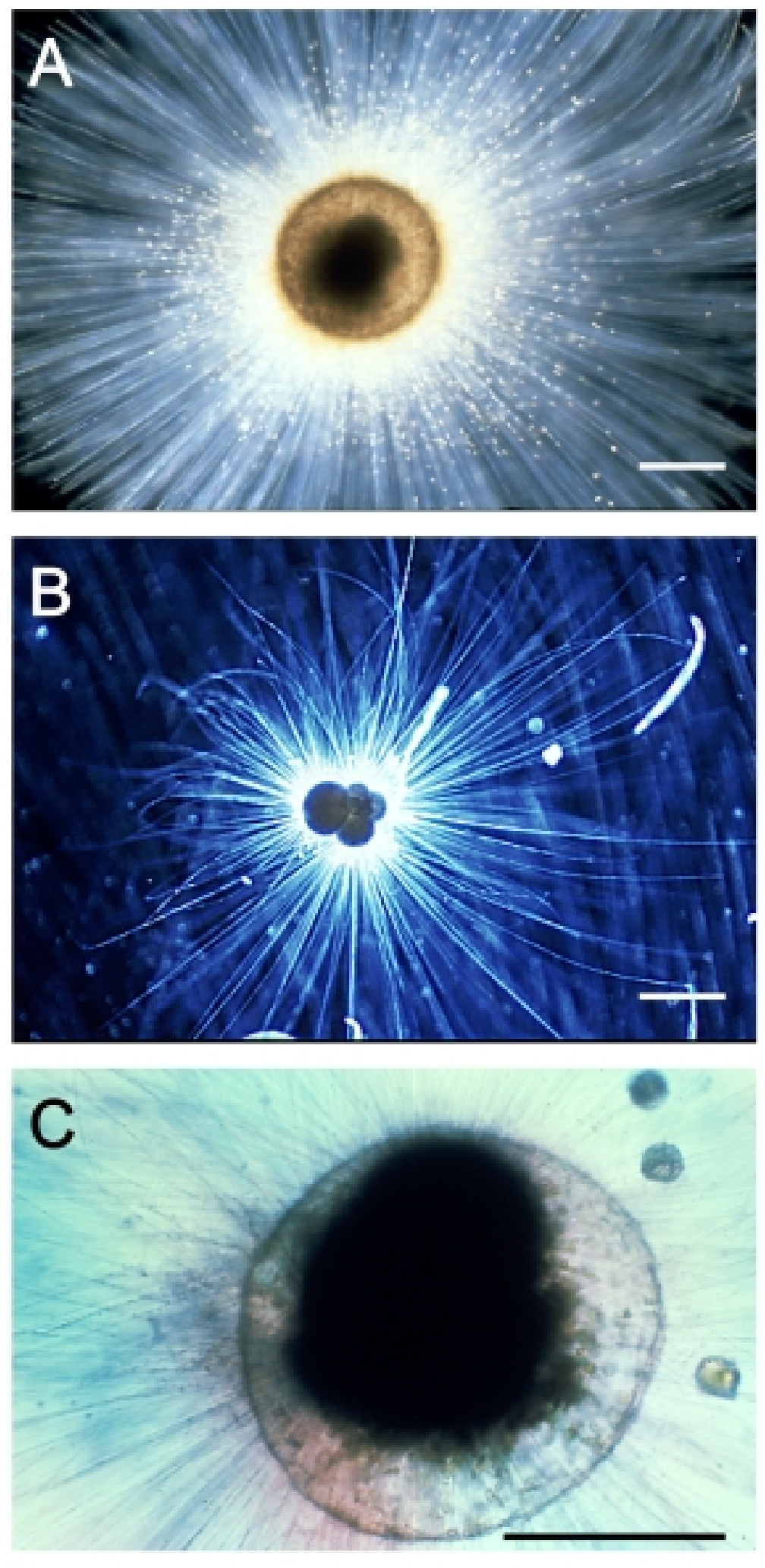

Fig. 1. Orbulina universa with symbionts (A; scale bar $=300 \mu \mathrm{m})$, Globigerina bulloides (B; scale bar $=300 \mu \mathrm{m}$ ), protruding membrane in O. universa $(\mathrm{C}$; scale bar $=300 \mu \mathrm{m})$. 
of geochemical information for paleoceanographic reconstructions (Bard et al. 1987; Kallel et al. 1988; Sautter and Thunell 1991). Contrary to most spinose species, an important part of its diet consists of algae as evidenced by the olive green to brownish coloration of the cytoplasm of freshly collected specimens. Recently, a study on the population dynamics (Schiebel et al. 1997) demonstrated a lunar periodicity of reproduction in this species as well. As evidenced by SEM, gametogenic calcification is much less pronounced than in $O$. universa, but the extent of GAM calcite addition has yet to be quantified.

\section{Culture Protocol}

Three sets of experiments were designed to investigate the effect of the carbonate chemistry on shell isotopic fractionation. Culture procedures followed standard protocols (e.g. Bemis et al. 1998; Hemleben et al. 1989). Briefy, O. universa and G. bulloides were collected by scuba divers from surface waters of the San Pedro Basin, Southern California Bight, U.S.A. and were maintained in laboratory culture at $17^{\circ} \mathrm{C}$ and $22^{\circ} \mathrm{C}\left( \pm 0.2^{\circ} \mathrm{C}\right)$. Specimens were grown in $0.8 \mu \mathrm{m}$ filtered sea water (FSW) whose carbonate chemistry was modified. Sea water $\Sigma \mathrm{CO}_{2}$ and total alkalinity $\left(\mathrm{alk}_{\mathrm{t}}\right)$ were modified via the addition of $\mathrm{Na}_{2} \mathrm{CO}_{3}$ and/or titration with $\mathrm{HCl}$ or $\mathrm{NaOH}$. The $\mathrm{pH}$ of the water was determined potentiometrically whereas alk $\mathrm{k}_{\mathrm{t}}$ and $\Sigma \mathrm{CO}_{2}$ were determined by titration and equilibrium calculations respectively. Coulometric determinations of a few sea water samples confirmed the accuracy of the calculated $\Sigma \mathrm{CO}_{2}$ values O(A. Sanyal, pers. comm. 1994). During the experiments, Southern California Bight ambient surface water $\mathrm{pH}$ was $8.13 \pm 0.02$ (at $22^{\circ} \mathrm{C}$ ) and ambient (alk was $2241 \pm 19 \mu \mathrm{eq} / \mathrm{kg}(\mathrm{n}=64)$. Calculated $\Sigma \mathrm{CO}_{2}$ was $2010 \pm 18 \mu \mathrm{mol} / \mathrm{kg}$, while $\left[\mathrm{CO}_{3}^{2-}\right]$ was calculated to have varied between $153-184 \mu \mathrm{mol} / \mathrm{kg}$.

The first two sets of experiments were designed to vary $\left[\mathrm{CO}_{3}^{2-}\right]$ at constant alk $\mathrm{t}_{\mathrm{t}}$ or at constant $\Sigma \mathrm{CO}_{2}$. Because $\left[\mathrm{CO}_{3}^{2-}\right]$ and $\mathrm{pH}$ covary linearly across the relevant $\mathrm{pH}$ range in sea water (e.g. 7.98.8 ), these two experiments did not allow us to mechanistically distinguish between $\mathrm{pH}$ and
$\left[\mathrm{CO}_{3}^{2-}\right]$ as a controlling factor. Therefore we designed a third set of experiments at constant $\mathrm{pH}$. The basic difference in the carbonate chemistry between the three experimental groups is that at constant alk $\mathrm{t}_{\mathrm{t}}$ and constant $\Sigma \mathrm{CO}_{2}$, the $\left[\mathrm{CO}_{3}^{2-}\right]$ decreases as $\left[\mathrm{CO}_{2} \mathrm{aq}\right]$ increases whereas at constant pH both carbon species covary (Fig. 2).

The $\left[\mathrm{CO}_{3}^{2-}\right]$ of the culture water was modified by: 1) elevating total alkalinity (alk $\mathrm{t}_{\mathrm{t}}$ ) to constant levels of $2842 \pm 80 \mu \mathrm{eq} / \mathrm{kg}(\mathrm{n}=29)$ and letting $\mathrm{pH}$ and $\Sigma \mathrm{CO}_{2}$ vary (Fig. 3a, b). We chose to run the experiments at elevated alk $\mathrm{k}_{\mathrm{t}}$ because removing inorganic carbon quantitatively by acidifying the medium is much more difficult than adding $\mathrm{\Sigma CO}_{2}$ or alkalinity. With an alk $\mathrm{t}_{\mathrm{t}}>2800 \mu \mathrm{eq} / \mathrm{kg},\left[\mathrm{CO}_{3}^{2-}\right]$ exceeding $600 \mu \mathrm{mol} / \mathrm{kg}$ could be achieved at ambient $\Sigma \mathrm{CO}_{2}$.

2) keeping $\Sigma \mathrm{CO}_{2}$ constant at $2032 \pm 15 \mu \mathrm{mol} / \mathrm{kg}$; $(\mathrm{n}=15)$ and letting $\mathrm{pH}$ and alk $\mathrm{t}_{\mathrm{t}}$ vary (Fig. $3 \mathrm{c}, \mathrm{d}$ and Fig. 4a, b). We chose to work with a slightly elevated experimental $\Sigma \mathrm{CO}_{2}$ for the same reason as above.

3) keeping $\mathrm{pH}$ constant at $8.15 \pm 0.05$ and letting $\Sigma \mathrm{CO}_{2}$ and alk $\mathrm{t}_{\mathrm{t}}$ vary. For $\left[\mathrm{CO}_{3}^{2-}\right]$ above ambient, we increased $\Sigma \mathrm{CO}_{2}$ by adding $\mathrm{Na}_{2} \mathrm{CO}_{3}$ and subsequently titrated with $\mathrm{HCl}$ to bring the $\mathrm{pH}$ back to 8.15. For $\left[\mathrm{CO}_{3}^{2-}\right]$ below ambient, however, we removed inorganic carbon by acidifying the medium

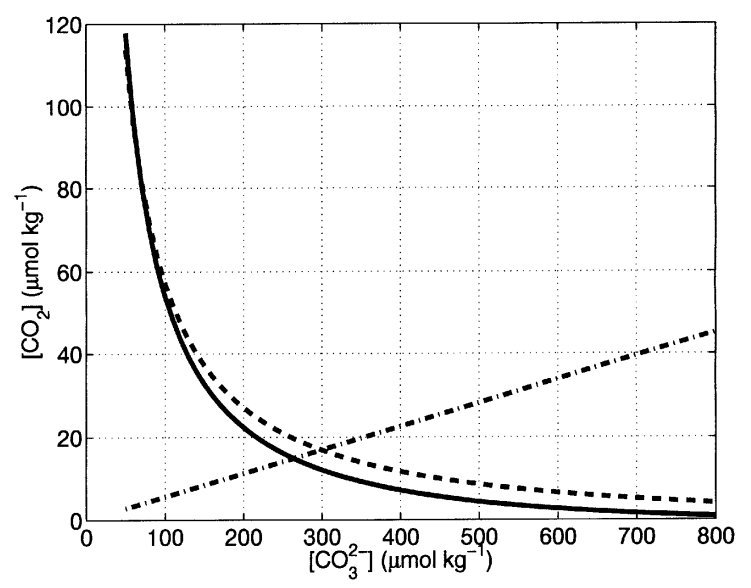

Fig. 2. Relationship between $\left[\mathrm{CO}_{3}^{2-}\right]$ and $\left[\mathrm{CO}_{2}\right.$ aq $]$ at constant alkalinity (broken line), constant $\Sigma \mathrm{CO}_{2}$ (solid line) and constant $\mathrm{pH}$ (straight broken line). 

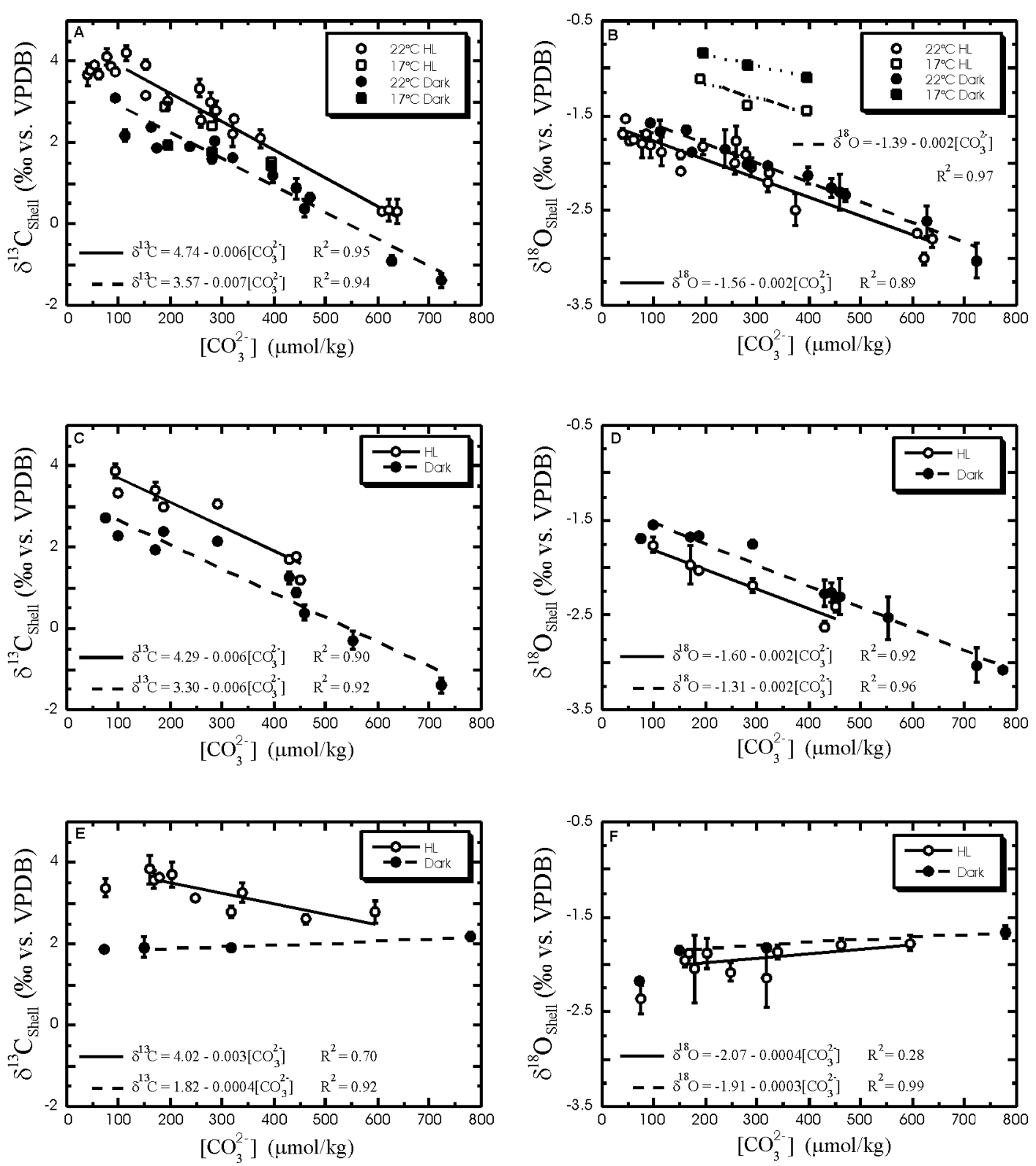

Fig. 3. Effect of $\mathrm{CO}_{3}^{2-}$ ion concentration on the $\delta^{13} \mathrm{C}$ and $\delta^{18} \mathrm{O}$ values of Orbulina universa shell calcite under constant alkalinity (a and b), constant $\Sigma \mathrm{CO}_{2}$ (c and d) and constant $\mathrm{pH}(\mathbf{e}$ and $\mathbf{f})$ conditions. Circles indicate specimens grown at $22^{\circ} \mathrm{C}$ and squares indicate specimens grown at $17^{\circ} \mathrm{C}$. Open symbols are mean values of specimens grown under high light (HL), closed symbols are specimens grown in the dark. Plotted data are group mean values \pm 1 s.d; most groups are composed of between 3 to 10 individual shell analyses. Lines are linear regressions fitted to the data. 

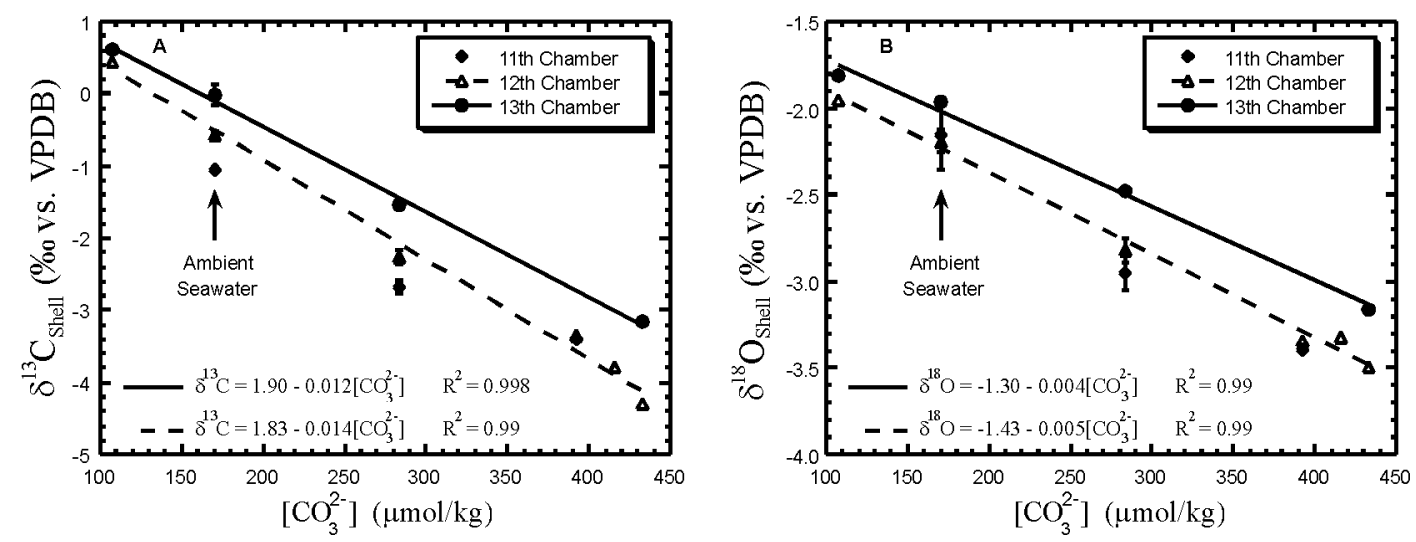

Fig. 4. Effect of $\mathrm{CO}_{3}^{2-}$ ion concentration on the $\delta^{13} \mathrm{C}(\mathbf{a})$ and $\delta^{18} \mathrm{O}(\mathbf{b})$ values of Globigerina bulloides chamber calcite under constant $\Sigma \mathrm{CO}_{2}$ conditions. Chambers from specific positions in the shell whorl are pooled and analysed together to eliminate the effect of ontogenetic isotope variability characteristic of this species (Spero and Lea 1996) Linear regression analyses are plotted for data from chambers 12 and 13, the last two chambers in the shell whorl.

to a calculated intermediate $\mathrm{pH}$ (Wolf-Gladrow pers. comm. 1994) at which the $\Sigma \mathrm{CO}_{2}$ attained a value that would yield the desired $\left[\mathrm{CO}_{3}^{2-}\right]$ at $\mathrm{pH}$ 8.15. After reaching the intermediate $\mathrm{pH}$, the headspace was replaced by a $\mathrm{N}_{2}$ atmosphere to prevent uptake of $\mathrm{CO}_{2}$ while raising the $\mathrm{pH}$ to 8.15 via addition of $\mathrm{NaOH}$.

The specimens were transferred to sealed 125 $\mathrm{ml}$ acid-cleaned, air-tight Pyrex ${ }^{\mathrm{TM}}$ jars containing the modified culture water and fed an one-day-old artemia nauplius every third day (total time in culture $\approx 6-8$ days). For $O$. universa, specimens were maintained in the dark and under nonphotoinhibitory $\mathrm{P}_{\max }$ light levels of $400-700 \mu \mathrm{E} \mathrm{m}^{-2}$ $\mathrm{s}^{-1}(1$ Einstein $=1$ mole photons $)$ to quantify the effect of symbiont photosynthesis on this relationship (Spero and Parker 1985). Following gametogenesis, the empty foraminiferal shells were archived for analysis. In O. universa, individual spherical chambers were used for isotope analysis. Globigerina bulloides chambers secreted during the experiments were amputated from the shell whorl and pooled according to chamber position (Spero and Lea 1996). The samples were roasted at $375{ }^{\circ} \mathrm{C}$ in vacuo and analyzed with a Fisons Optima isotope ratio mass spectrometer using an Isocarb common acid bath autocarbonate system at $90{ }^{\circ} \mathrm{C}$.
To confirm the stability of the carbonate chemistry and isotopic composition of the culture water throughout each experiment, water samples were collected at the start and end of each experiment to analyse alkalinity, $\Sigma \mathrm{CO}_{2}, \delta^{13} \mathrm{C}_{\Sigma \mathrm{CO} 2}$ and $\delta^{18} \mathrm{O}_{\text {water }}$.

\section{Cytoplasmic Inorganic Carbon Pool}

To explain the stable carbon isotopic signature in a variety of calcifying organisms, a so called internal inorganic carbon pool has been proposed (e.g. Erez 1978a; Erez 1978b; Goreau 1963; Goreau 1977; Kuile et al. 1989; Weber and Woodhead 1970). To investigate the presence of such a cytoplasmic inorganic carbon pool in $O$. universa, pulse-chase experiments were designed. Freshly collected $O$. univers $a$ were fed and placed in ${ }^{13} \mathrm{C}$ spiked solution (after a rinse through a ${ }^{13} \mathrm{C}$-spiked medium). The specimens were monitored at regular intervals to catch the moment of membrane protrusion (Fig. 1c) At this stage, the specimens were rinsed three times in normal FSW, transferred to unspiked culture water and allowed to calcify the spherical chamber (see also Lea et al. 1995). Specimens were kept in the dark or at $\mathrm{P}_{\max }$ light levels and fed every third day. After gametogenesis, the specimens were archived and processed as described above. 
A spike stock-solution was prepared by dissolving $7 \mathrm{mg}$ of $99.1 \% \mathrm{Na}_{2}{ }^{13} \mathrm{CO}_{3}$ in $100 \mathrm{ml}$ deionized water. From this stock-solution $35 \mathrm{ml}$ were added to $11 \mathrm{FSW}\left(2028 \mu \mathrm{Mol} \Sigma \mathrm{CO}_{2} ; \delta^{13} \mathrm{C}_{\Sigma \mathrm{CO} 2} \approx 2 \%\right.$ ). Initial and final samples of the ${ }^{13} \mathrm{C}$-spiked culture medium were measured, indicating that the average spike was $77.8 \% \circ \pm 5.2 \% \circ(\mathrm{n}=11)$. The pulseand chase-solution for each experiment were taken from the same batch of modified sea water and therefore had identical carbonate chemistry. The $\left[\mathrm{CO}_{3}^{2-}\right]$ varied between 153 and $517 \mu \mathrm{mol} / \mathrm{kg}$ at an average constant alkalinity of $2563 \pm 371 \mu \mathrm{eq} / \mathrm{kg}$.

\section{Results}

Water samples collected at the start and end of each experiment showed that the carbonate chemistry (as determined by $\mathrm{pH}$, alk $\mathrm{t}_{\mathrm{t}}$ and equilibrium calculations) remained constant throughout the experiments. The isotope chemistry $\left(\delta^{13} \mathrm{C}_{\mathrm{SCO} 2}\right.$ and $\delta^{18} \mathrm{O}_{\text {water }}$ ) of the culture medium remained fairly constant as well. Analyses show that $\delta^{18} \mathrm{O}_{\text {water }}$ was constant at $-0.23 \pm 0.05 \%$ (vs. VSMOW) $(\mathrm{n}=100)$. The $\delta^{13} \mathrm{C}_{\mathrm{SCO} 2}$ depended on the amount of $\mathrm{Na}_{2} \mathrm{CO}_{3}$ that was added to modify the carbonate chemistry in each experiment. Analysis of initial and final water show that $\delta^{13} \mathrm{C}_{\mathrm{SCO} 2}$ varied on average 0.16 $\pm 0.10 \%$ o $(\mathrm{n}=30)$.

All foraminiferal $\delta^{13} \mathrm{C}$ data have been standardized to a $\delta^{13} \mathrm{C}_{\Sigma \mathrm{CO} 2}=2.00 \%$ (ambient sea water $\delta^{13} \mathrm{C}_{\Sigma \mathrm{CO} 2}=1.90 \pm 0.08 \%$ o, $\mathrm{n}=18$ ) by adding or subtracting the difference between $2.00 \%$ and the measured experimental water $\delta^{13} \mathrm{C}_{\Sigma \mathrm{CO} 2}$ to each shell value. Here $\delta^{18} \mathrm{O}$ (and similar for $\delta^{13} \mathrm{C}$ ) = $\left[\left({ }^{18} \mathrm{O} /{ }^{16} \mathrm{O}_{\text {sample }} /{ }^{18} \mathrm{O} /{ }^{16} \mathrm{O}_{\text {standard }}\right)-1\right] \times 1000$. All isotope values are relative to VPDB unless noted. To convert $\delta^{18} \mathrm{O}_{\mathrm{w}}$ values from the VSMOW to VPDB scale, the most recent correction of $-0.27 \%$ o (Hut 1987) was used.

\section{Constant Total Alkalinity Experiment}

Results demonstrate that $O$. universa shell $\delta^{13} \mathrm{C}$ and $\delta^{18} \mathrm{O}$ values decrease approximately $3.9 \%$ and $1.5 \%$ respectively as carbonate increases from 41 to $642 \mu \mathrm{mol} / \mathrm{kg}$ (pH increases from 7.38 to 8.83) (Fig. 3a, b). Shell $\delta^{13} \mathrm{C}$ values do not increase further when sea water $\left[\mathrm{CO}_{3}{ }^{2-}\right]$ drops be- low ca. $100 \mu \mathrm{mol} / \mathrm{kg}$. Comparison of foraminifers grown under high light $(\mathrm{HL}=$ maximum symbiont photosynthesis) with specimens maintained in the dark (no symbiont photosynthetic activity) indicates that $\mathrm{HL}$ shells are enriched in ${ }^{13} \mathrm{C}$ by $1.1 \%$ and depleted in ${ }^{18} \mathrm{O}$ by $0.3 \%$ relative to dark specimens. These offsets are seen across the full range of $\left[\mathrm{CO}_{3}{ }^{2-}\right]$. Although the effect of symbiont photosynthesis on shell $\delta^{13} \mathrm{C}$ and $\delta^{18} \mathrm{O}$ was documented previously (Spero and DeNiro 1987; Spero and Lea 1996; Spero and Williams 1988), the fact that the $\delta^{13} \mathrm{C} /\left[\mathrm{CO}_{3}{ }^{2}{ }^{-}\right]$and $\delta^{18} \mathrm{O} /\left[\mathrm{CO}_{3}{ }^{2}-\right]$ slopes from HL and dark experiments are ca. 0.0065 and $0.002 \% / \mu \mathrm{mol} \mathrm{kg}{ }^{-1}$ respectively (Table 1 ) indicates that symbiont photosynthesis does not affect the stable isotope:carbonate ion relationship.

Six experiments were carried out at a $5^{\circ} \mathrm{C}$ lower culture temperature. Although, the temperature decrease does not seem to significantly affect the $\delta^{13} \mathrm{C} /\left[\mathrm{CO}_{3}^{2-}\right]$ nor the $\delta^{18} \mathrm{O} /\left[\mathrm{CO}_{3}^{2-}\right]$ relationship, additional experiments are needed to further bolster this conclusion.

\section{Constant Total Inorganic Carbon Experiment}

In a second series of experiments, we manipulated the carbonate concentration between $75-774 \mu \mathrm{mol} /$ $\mathrm{kg}$ (pH increase from 7.87 to 8.97 ) by varying alk $_{\mathrm{t}}$ and maintaining $\Sigma \mathrm{CO}_{2}$ at ambient values (Fig 3c, d). Orbulina universa shell $\delta^{13} \mathrm{C}$ and $\delta^{18} \mathrm{O}$ decreased as $\left[\mathrm{CO}_{3}^{2-}\right]$ increased, with similar slopes as under constant alk: 0.006 and $0.002 \% / \mu \mathrm{mol} \mathrm{kg}$ ${ }^{1}$ respectively (Table 1). Again, comparison of foraminifers grown under HL with specimens maintained in the dark (no symbiont photosynthetic activity) indicates that $\mathrm{HL}$ shells are enriched in ${ }^{13} \mathrm{C}$ by $1.1 \% 0$ and depleted in ${ }^{18} \mathrm{O}$ by $0.4 \%$ relative to dark specimens and that these offsets are constant across the full range of $\left[\mathrm{CO}_{3}^{2-}\right]$.

We also cultured the non-symbiotic species, G. bulloides, across a $\left[\mathrm{CO}_{3}^{2-}\right]$ range of 103-436 $\mu \mathrm{mol} / \mathrm{kg}$ at constant $\Sigma \mathrm{CO}_{2}$. Because G. bulloides displays a large chamber-to-chamber ontogenetic effect for both $\delta^{13} \mathrm{C}$ and $\delta^{18} \mathrm{O}$ (Spero and Lea 1996), we amputated chambers secreted during the 
experiments and pooled them according to their discrete positions in the shell whorl for stable isotope measurement (Fig. 4a, b). Regression analyses on data from the 11th, 12th and 13th chamber groups yield similar $\delta^{13} \mathrm{C} /\left[\mathrm{CO}_{3}^{2-}\right]$ and $\delta^{18} \mathrm{O} /\left[\mathrm{CO}_{3}^{2-}\right]$ slopes demonstrating that ontogenetic effects have little or no affect on this relationship. However, the average G. bulloides $\delta^{13} \mathrm{C} /\left[\mathrm{CO}_{3}^{2-}\right]$ and $\delta^{18} \mathrm{O} /\left[\mathrm{CO}_{3}^{2-}\right]$ slopes of 0.013 and $0.0045 \%$ ol $\mu \mathrm{mol} \mathrm{kg}{ }^{-1}$ are twice that of $O$. universa (Table 1 ).

\section{Constant pH Experiment}

Results demonstrate that shell $\delta^{13} \mathrm{C}$ and $\delta^{18} \mathrm{O}$ values of $O$. universa grown in the dark are approximately constant ( $2.0 \%$ and $-1.75 \%$ respectively) as carbonate increases from ambient to $780 \mu \mathrm{mol}$ $\left[\mathrm{CO}_{3}^{2-}\right] / \mathrm{kg}\left(\Sigma \mathrm{CO}_{2}\right.$ increases from 748 to 9,273

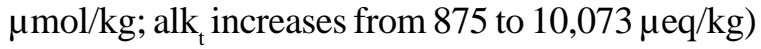
(Fig. 3e, f). If anything, there is an insignificant but distinct trend towards slightly higher values for $\delta^{13} \mathrm{C}$ and $\delta^{18} \mathrm{O}$ with increasing $\left[\mathrm{CO}_{3}^{2-}\right]$ in the dark. Comparison of foraminifers grown under HL (maximum symbiont photosynthesis) with specimens maintained in the dark indicates that HL shells are enriched in ${ }^{13} \mathrm{C}$ by ca. $1.5 \%$ at ambient $\left[\mathrm{CO}_{3}^{2-}\right]$, but that this enrichment decreases as $\left[\mathrm{CO}_{3}^{2-}\right]$ increases. Because this offset is not constant across the full range of $\left[\mathrm{CO}_{3}^{2-}\right]$, symbiont photosynthesis does have an effect on the $\delta^{13} \mathrm{C} /\left[\mathrm{CO}_{3}^{2-}\right]$ relationship under constant $\mathrm{pH}$. On the contrary, the $\delta^{18} \mathrm{O}$ values in the light are slightly depleted compared to those in the dark and the offset $(\approx 0.1 \%$ o $)$ is more or less constant across the full range of $\left[\mathrm{CO}_{3}^{2-}\right]$.

\section{Inorganic Carbon Pool (Pulse-Chase) Experiment}

After a mean incubation time of two days in the "pulse" solution $\left(\delta^{13} \mathrm{C}_{\Sigma \mathrm{CO} 2}=77.8 \% \circ \pm 5.2 \%\right.$ ) , the specimens were transferred, upon membrane protrusion, to a "chase" solution with the same carbon-

\begin{tabular}{lllll}
\hline \multicolumn{1}{c}{ Species } & \multicolumn{2}{c}{ Experiment } & \multicolumn{2}{c}{ Regression Slope } \\
& & & $\frac{\delta^{13} \mathrm{C}}{\left[\mathrm{CO}_{3}^{2-}\right]}$ & $\frac{\delta^{18} \mathrm{O}}{\left[\mathrm{CO}_{3}^{2-}\right]}$ \\
\hline \multirow{2}{*}{ Orbulina universa } & Constant Alkalinity & High Light & 0.006 & 0.002 \\
& & Dark & 0.007 & 0.002 \\
& Constant $\Sigma \mathrm{CO}_{2}$ & High Light & 0.006 & 0.002 \\
& & High Light* & 0.006 & 0.0012 \\
& & Dark & 0.006 & 0.002 \\
& & 12th Chamber & 0.014 & 0.005 \\
& & 13th Chamber & 0.012 & 0.004 \\
& & 11th Chamber* & 0.013 & 0.005 \\
& & 12th Chamber* & 0.012 & 0.004 \\
& & 13th Chamber* & 0.013 & 0.004 \\
\hline & & & &
\end{tabular}

* Data from a feeding experiment not described here

Table 1. Experiment regression slopes. 
ate chemistry as the "pulse" solution, fed as usual and left to calcify the adult chamber and undergo gametogenesis. It can be calculated that the small amount of the "pulse" solution that is enclosed by the membrane and inevitably transferred to the chase culture medium does not affect the shell $\delta^{13} \mathrm{C}$ even if all of this "enclosed" carbon is used for calcification (cf. Lea et al. 1995). The $\delta^{13} \mathrm{C}$ values of the spiked specimens were slightly higher than those of the control group (Fig. 5a-d) but mass balance calculations demonstrate that less than 1 $\%$ of the carbon used for calcification originates from the spike and hence that, if present at all, the inorganic carbon pool is insignificant.
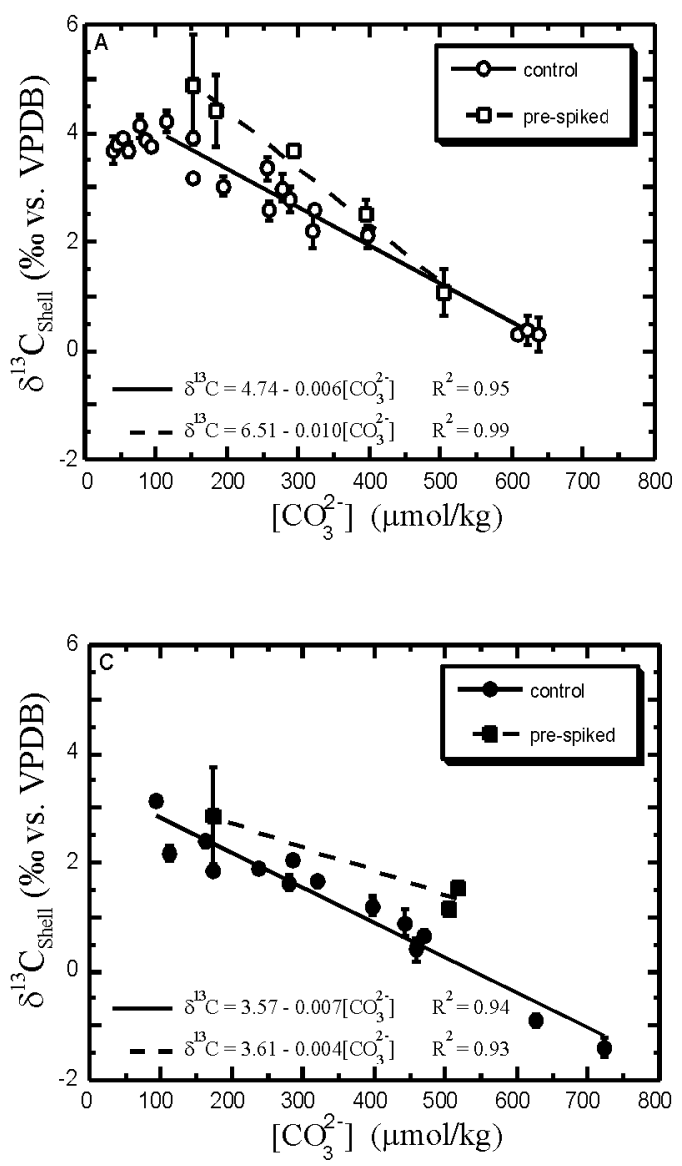

\section{Discussion}

Because the sea water carbonate chemistry system was modified in fundamentally different ways (varying proportions of $\Sigma \mathrm{CO}_{2}$ and alk $\mathrm{k}_{\mathrm{t}}$ yet produced indistinguishable regression slopes, the observed stable isotope:carbonate ion relationship is real and not an artifact of our experiments. In addition, identical $\delta^{13} \mathrm{C}$ and $\delta^{18} \mathrm{O}$ values of pre- and post-gametogenic shells (Spero et al. 1997) demonstrate that the relationships are a function of calcification during normal growth and not due to inorganic precipitation on the surface of the empty post-gametogenic shell.
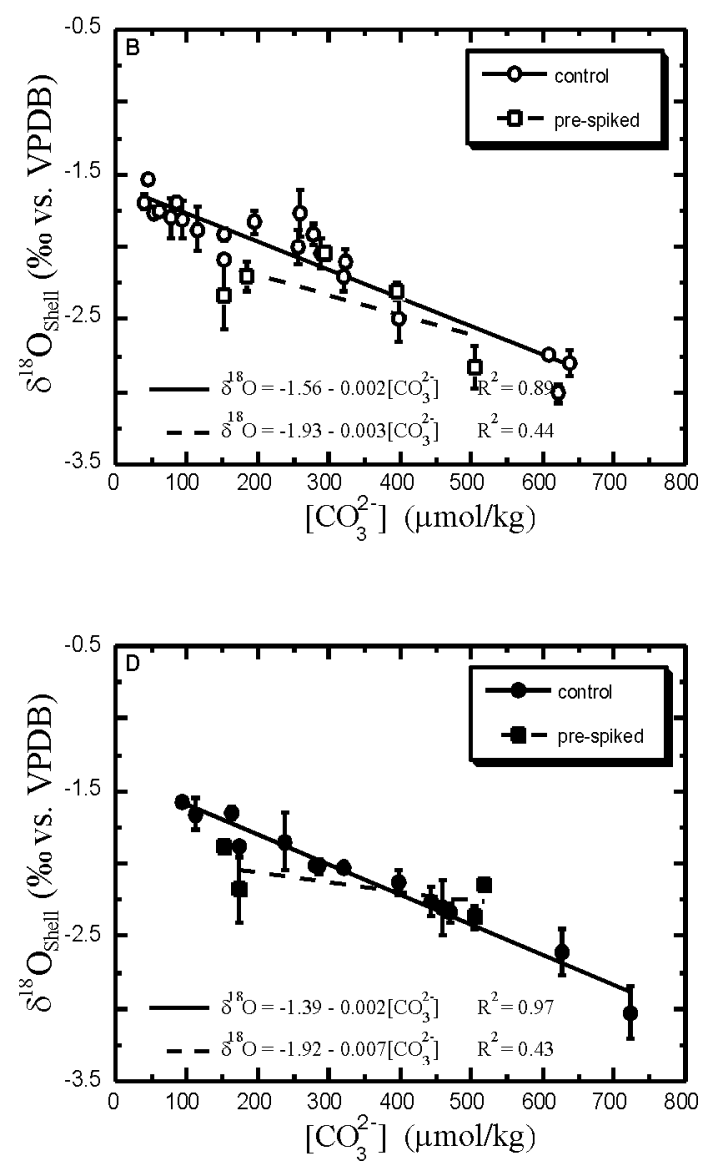

Fig. 5. Effect of pre-culture labeling $\left(\delta^{13} \mathrm{C}_{\Sigma \mathrm{CO} 2}=77.8 \%\right.$ ) on the $\delta^{13} \mathrm{C}$ and $\delta^{18} \mathrm{O}$ values (under constant alkalinity conditions) as a function of $\mathrm{CO}_{3}^{2-}$ ion concentration (squares). For comparison, the data of the constant alkalinity experiment (Fig. 2 a,b) are also plotted (circles). Open symbols (a, b) are mean values of specimens grown under high light, (HL); closed symbols (c, d) are specimens grown in the dark. Plotted data are group mean values \pm 1 s.d. The lines are linear regressions fitted to the data. 
The experiments carried out with the symbiont barren G. bulloides as well as the dark experiments with $O$. universa clearly demonstrate that whatever controls the stable isotope:carbonate chemistry relationship is independent of symbiont activity. Experiments carried out at a $5^{\circ} \mathrm{C}$ lower temperature further suggest that this relationship is also independent of temperature. In addition, an unexpected stable oxygen isotope: $\left[\mathrm{CO}_{3}^{2-}\right]$ relationship (also independent of symbiont activity and temperature) was found that cannot be explained in terms of known "vital effects". These observations force us to reassess previously proposed fractionation mechanisms.

In the following sections we will first discuss inorganic equilibrium and kinetic fractionation mechanisms. We will then discuss the influence of respiration and photosynthesis and finally propose a combination of mechanisms that control the isotopic composition of symbiont barren and symbiont bearing foraminifers.

\section{Equilibrium and Kinetic Fractionation}

Mass balance calculations (Mook et al. 1974; Zhang et al. 1995) show that the $\delta^{13} \mathrm{C}$ :carbonate chemistry relationship documented here cannot be explained in terms of equilibrium fractionation, i.e. by a simple redistribution of isotopes between the dissolved carbon species (Fig. 6). The influence of temperature ( 17 vs. $22{ }^{\circ} \mathrm{C}$ ) on the isotopic redistribution between the carbon species is only discernible in the $\delta^{13} \mathrm{C}$ composition of $\mathrm{CO}_{2}$. The $\delta^{18} \mathrm{O}$ signal of the carbon species is insensitive to changes in the carbonate chemistry because the water reservoir is huge compared to the $\Sigma \mathrm{CO}_{2}$ reservoir.

With regard to kinetic fractionation, the early inorganic precipitation experiments of McCrea (1950) are of particular interest. He demonstrated that the ${ }^{18} \mathrm{O} /{ }^{16} \mathrm{O}$ ratio of rapidly precipitated $\mathrm{CaCO}_{3}$ decreases with increasing percentage $\mathrm{CO}_{3}^{2-}$ in solution. McCrea proposed that the oxygen isotope equilibrium fractionation between the sum of the dissolved carbonate species and water is linearly related to the equilibrium between the carbonate species, a conclusion that was, more than 40 years later, confirmed by Usdowski and Hoefs (1993). Comparison of our experimental $O$. universa data with those of McCrea show remarkable similarity in the slopes of the relationships (Fig. 7). We note that the larger $G$. bulloides $\delta^{18} \mathrm{O}:\left[\mathrm{CO}_{3}^{2-}\right]$ relationship demonstrates that additional fractionation mechanisms are operative. McCrea proposed that the $\delta^{18} \mathrm{O}:\left[\mathrm{CO}_{3}^{2-}\right]$ relationship for inorganic precipitates could be a function of calcification rate. This conclusion is not supported by our observations because: 1) Above ambient $\left[\mathrm{CO}_{3}^{2-}\right]$, the average shell weight, in both the dark and HL, is fairly constant (albeit variable) with increasing $\left[\mathrm{CO}_{3}^{2-}\right]$. Because the life span of $O$. universa was similar between and within treatments, the average calcification rate must have been relatively constant in the $\left[\mathrm{CO}_{3}^{2-}\right]$ range above ambient as well. On the contrary, below ambient $\left[\mathrm{CO}_{3}^{2-}\right]$, the calcification rates in the dark and in HL decrease significantly with decreasing $\left[\mathrm{CO}_{3}^{2-}\right]$ (Fig. 8). Thus, if it is assumed that changes in the calcification rate control the $\delta^{18} \mathrm{O}$ fractionation we would expect a clear break in the shell $\delta^{18} \mathrm{O}:\left[\mathrm{CO}_{3}^{2-}\right]$ relationship at ambient $\left[\mathrm{CO}_{3}^{2-}\right]$. On the contrary, the shell $\delta^{18} \mathrm{O}$ : $\left[\mathrm{CO}_{3}^{2-}\right]$ relationship decreases linear across the full $\left[\mathrm{CO}_{3}^{2-}\right]$ range. 2) The difference in shell weight, and by extension the difference in calcification rate, between the HL and dark experiments (cf. Lea et al. 1995) is larger than the difference in shell weight

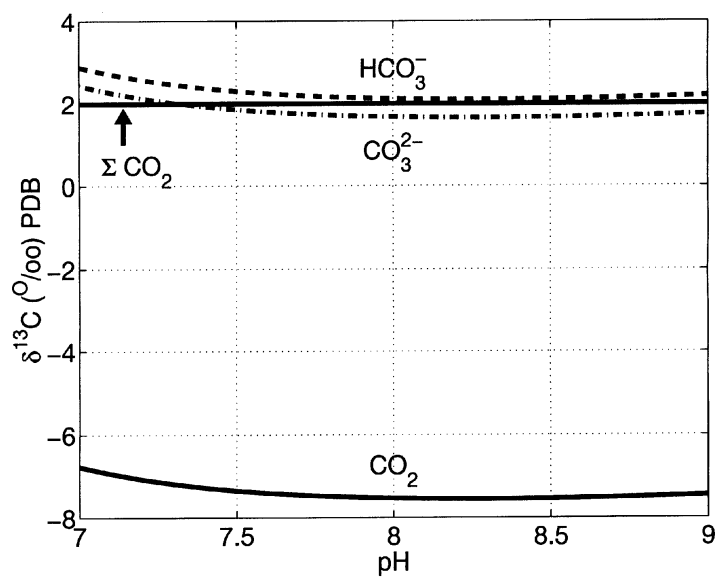

Fig. 6. Mass balance calculations (Mook et al. 1974; Zhang et al. 1995) show the redistribution of isotopes between the dissolved carbon species as a function of $\mathrm{pH}$. 
between ambient and high $\left[\mathrm{CO}_{3}^{2-}\right]$ (Fig. 8). Consequently, if the fractionation is controlled by the calcification rate, the light/dark effect on $\delta^{18} \mathrm{O}$ should be larger than the $\left[\mathrm{CO}_{3}^{2-}\right]$ effect. On the contrary, the light/dark shift in $\delta^{18} \mathrm{O}$ is on the average $-0.35 \%$ o for $O$. universa and constant across the full range of the experimental $\left[\mathrm{CO}_{3}^{2-}\right]$ while the depletion is approximately $1.5 \%$ over a $\left[\mathrm{CO}_{3}^{2-}\right]$ range of ca. 600 and $700 \mu \mathrm{mol} / \mathrm{kg}$ at constant alk $_{\mathrm{t}}$ and constant $\Sigma \mathrm{CO}_{2}$, respectively. Shells of G. bulloides are depleted by $1.4 \%$ across a $\left[\mathrm{CO}_{3}^{2-}\right]$ range of only $333 \mu \mathrm{mol} / \mathrm{kg}$ (at constant $\Sigma \mathrm{CO}_{2}$ ). Again, this suggests that the calcification rate does not control ${ }^{18} \mathrm{O}$ incorporation. 3) Finally, the final shell weight of $O$. universa, ranging between 10 to $70 \mu \mathrm{g}$, is very variable between and within treatments (Fig. 8). Thus, if the calcification rate is the controlling factor, the correlation between the oxygen isotopic composition of the shell and the percentage carbonate ion in solution (Fig. 7) should be very low. At this stage we therefore have to conclude that the $\delta^{18} \mathrm{O}:\left[\mathrm{CO}_{3}^{2-}\right]$ relationship for inorganic and biological precipitates is probably not a function of calcification rate as proposed by McCrea. However, because we find it difficult to believe that the rate at which a calcifying organism accretes $\mathrm{CaCO}_{3}$ is not a fundamental factor for isotope fractionation, additional experiments will have to be carried out to confirm this hypothesis. It should also be noted that although the similarity in life span of $O$. universa between and within treatments can be used to roughly quantify calcification rate (because spherical chamber formation is a continuous process) it cannot be applied to $G$. bulloides because chambers are formed discretely.

More importantly, the similarity between our investigation and the inorganic precipitate study of McCrea implies a kinetic mechanism which would affect all calcifying organisms and inorganic precipitates. Evidence for a common kinetic fractionation mechanism exists in corals and other invertebrate groups. For instance, McConnaughey (1989b) demonstrated that the carbon and oxygen isotopic composition of symbiotic and nonsymbiotic coral skeletons can vary significantly across skeletal surfaces that were presumably secreted synchronously. In the non-photosynthetic species, Tubastrea, the values covary with a posi-

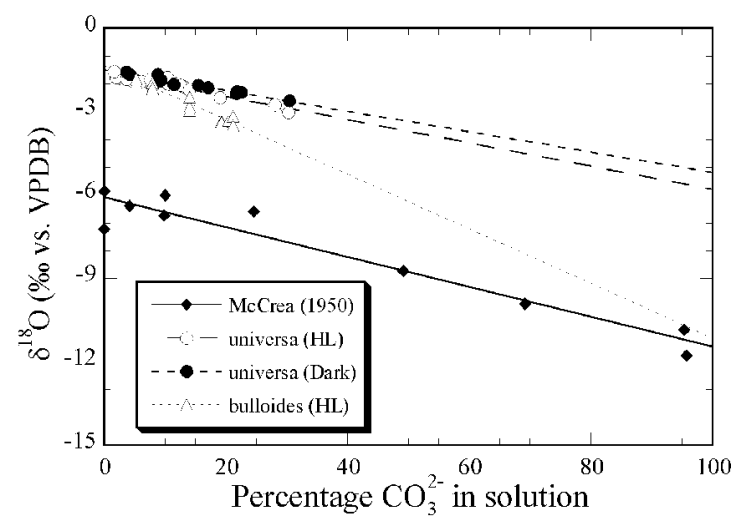

Fig. 7. Comparison of high light (open circles) and dark (closed circles) $O$. universa $\delta^{18} \mathrm{O}$ data from the constant alkalinity experiment and high light $G$. bulloides $\delta^{18} \mathrm{O}$ data (open triangle) from the constant $\Sigma \mathrm{CO}_{2}$ experiment with inorganic precipitate results from McCrea (1950). Oxygen isotope data are plotted vs. percentage $\mathrm{CO}_{3}^{2-}$ in solution where: \% $\mathrm{CO}_{3}^{2-}=\left[\mathrm{CO}_{3}^{2-}\right] /\left(\left[\mathrm{CO}_{3}^{2-}\right]+\left[\mathrm{HCO}_{3}^{-}\right]\right)$. Note that the slopes of the $O$. universa data are indistinguishable from that of the McCrea data set but that the slope of the G. bulloides data is much steeper.

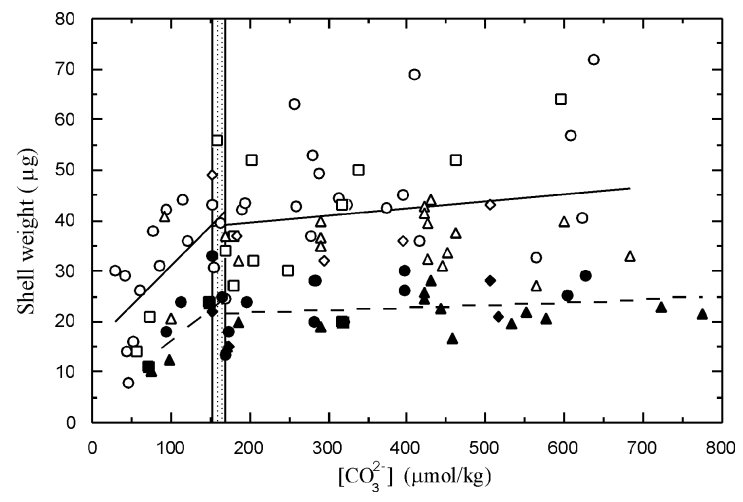

Fig. 8. Shell weights of $O$. universa plotted as a function of $\mathrm{CO}_{3}^{2-}$ ion concentration. Chamber mass data for $G$. bulloides were inconclusive and are therefore not shown. The shaded area represents the range of ambient $\left[\mathrm{CO}_{3}^{2-}\right]$. Circles, triangles and squares represent the constant alkalinity, $\Sigma \mathrm{CO}_{2}$ and $\mathrm{pH}$ experiment, respectively. Diamonds indicate the pulse-chase experiments. Open symbols are mean values of specimens grown under high light (HL), closed symbols are specimens grown in the dark. Linear regressions were fitted to data below and above ambient $\left[\mathrm{CO}_{3}^{2-}\right]$; $\mathrm{HL}$ data (solid line) and dark data (broken line). 
tive $\delta^{18} \mathrm{O} / \delta^{13} \mathrm{C}$ slope of 0.29 . The foraminiferal $\delta^{18} \mathrm{O} / \delta^{13} \mathrm{C}$ slopes derived from the experimental data are virtually identical to Tubastrea, with values ranging between 0.29 and 0.33 (Fig. 9). Other ahermatypic corals, calcareous algae and invertebrates such as cidaroid urchins show similar oxygen and carbon isotope covariance (McConnaughey 1989b; Wefer and Berger 1991) although the $\delta^{18} \mathrm{O} / \delta^{13} \mathrm{C}$ slopes can differ from the experimental range reported here. For instance, in symbiont-bearing organisms such as the coral Pavona, the slope can approach unity or even change sign due to the additional ${ }^{13} \mathrm{C}$-enriching effect of symbiont photosynthesis (McConnaughey 1989b). Aside from organisms that display a large symbiont effect, the slope relationship similarities among different protozoans, invertebrate groups and some calcifying algae suggest that a common kinetic mechanism is responsible for the observed covariance. Moreover, the linearity between $\delta^{18} \mathrm{O}$ and $\delta{ }^{13} \mathrm{C}$ suggests that whatever controls the fractionation of oxygen also affects carbon.

McConnaughey (1989a) has proposed that the fractionation observed in Tubastrea occurs during $\mathrm{CO}_{2}$ hydration and hydroxylation to form $\mathrm{HCO}_{3}^{-}$.

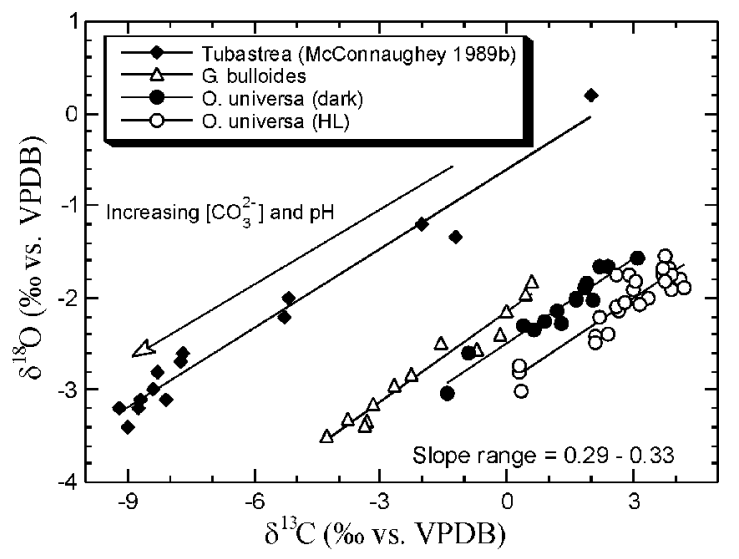

Fig. 9. Comparision of foraminiferal carbon and oxygen isotope data from all experiments with data from the nonsymbiotic coral, Tubastrea spp (McConnaughey 1989b). The similarity of the positive covariance between coral (aragonite) and foraminiferal (calcite) stable isotopes suggest that similar mechanisms are responsible for the observed variations. In this plot, $\left[\mathrm{CO}_{3}^{2-}\right]$ and $\mathrm{pH}$ increase towards the origin.
The rates of hydration and hydroxylation are $\mathrm{pH}$ dependent and are the rate-limiting steps responsible for the kinetic discrimination against the heavier ${ }^{18} \mathrm{O}$ and ${ }^{13} \mathrm{C}$ isotopes in the calcifying microenvironment adjacent to the skeleton. McConnaughey further argues that $\mathrm{CO}_{2}$ hydration and hydroxylation reactions may exhibit different kinetic isotope effects and that the balance between these two reactions changes with $\mathrm{pH}$. Subsequent isotopic equilibration between $\mathrm{HCO}_{3}^{-}$and $\mathrm{CO}_{3}^{2-}$ is effectively instantaneous because the protonation of $\mathrm{CO}_{3}^{2-}$ and the deprotonation of $\mathrm{HCO}_{3}^{-}$are extremely fast. With regard to $\delta^{18} \mathrm{O}$, McConnaughey's prediction is in agreement with results from inorganic precipitation experiments (Usdowski et al. 1991).

\section{pH or Carbonate Ion Control}

Our experiments allow us to mechanistically distinguish between $\mathrm{pH}$ and $\left[\mathrm{CO}_{3}^{2-}\right]$ as controlling factors for the observed fractionation. The fact that under constant $\mathrm{pH}, \delta^{13} \mathrm{C}$ and $\delta^{18} \mathrm{O}$ of shells kept in the dark do not vary with increasing $\left[\mathrm{CO}_{3}^{2-}\right]$ suggest that $\mathrm{pH}$, as proposed by McConnaughey (1989a), controls the stable isotope fractionation and not $\left[\mathrm{CO}_{3}^{2-}\right]$. This conclusion is supported by experiments that were recently carried out with $G$. sacculifer at constant $\mathrm{pH}$ (Bijma, Spero and Lea unpubl. results). Fig. 10a and b demonstrate that, at constant alkalinity, below $\mathrm{pH} \approx 8$ the fractionation is approximately constant (the ${\mathrm{C} \Sigma \mathrm{CO}_{2}}_{2}$ experiments suggest a similar trend). Apparently, the partitioning of the hydration and hydroxylation does not change very much in that $\mathrm{pH}$ range. One could argue that, although insignificant, the dark constant $\mathrm{pH}$ experiments show a trend towards higher values for both $\delta^{13} \mathrm{C}$ and $\delta^{18} \mathrm{O}$ at higher $\left[\mathrm{CO}_{3}^{2-}\right]$. At present we have no explanation for this observation. It can neither be justified by a redistribution of isotopes between the dissolved carbon species as $\mathrm{pH}$ is more or less constant (Fig. 11c) nor by a change in the relative proportion of light metabolic $\mathrm{CO}_{2}$ incorporation (because the $\delta^{18} \mathrm{O}$ difference between respired and bulk $\mathrm{CO}_{2}$ is negligible as will be demonstrated later).

An intriguing question is why the shell stable isotope composition responds linear to $\left[\mathrm{CO}_{3}^{2-}\right]$ 
(Figs. 3,4) but not to $\mathrm{pH}$ (Fig. 10)? Intuitively one would conclude that kinetic fractionation is apparently controlled by the $\left[\mathrm{CO}_{3}^{2-}\right]$. However, in a nonequilibrium situation where the kinetic fractionation is dependent on the balance between $\mathrm{CO}_{2}$ hydration and hydroxylation as suggested by McConnaughey (cf. Fig. 6 in McConnaughey 1989a) and both reactions exhibit different but constant kinetic isotope effects, the $\mathrm{pH}-\delta^{13} \mathrm{C}_{\mathrm{\Sigma CO} 2}$ (cf. Fig. 6) and the $\mathrm{pH}-\delta^{18} \mathrm{O}_{\Sigma \mathrm{CO} 2}$ relationships are not constant but apparently decrease with increasing $\mathrm{pH}$ (Fig. 10a-d). Because the $\mathrm{pH} /\left[\mathrm{CO}_{3}^{2-}\right]$ relationship in the constant alkalinity and the constant $\Sigma \mathrm{CO}_{2}$ experiments is also non-linear (Fig. 11a, b), the $\left[\mathrm{CO}_{3}^{2-}\right]$ :stable isotope relationships in these ex- periments turn out to be linear. On the other hand, as argued before, we believe that the calcification rate (for instance, the time available for isotopic equilibration between $\mathrm{CO}_{3}^{2-}$ and solid $\mathrm{CaCO}_{3}$ before subsequent layers prevent isotopic exchange) should play an important role and is likely to depend on the saturation state $(\Omega)$ and hence on the $\left[\mathrm{CO}_{3}^{2-}\right]$. Independent of which factor ultimately controls the relationship between the carbonate chemistry and isotopic fractionation, the dependence may be expressed as a function of $\mathrm{pH}$ or $\left[\mathrm{CO}_{3}^{2-}\right]$. For obvious reasons we prefer the linear relationship with $\left[\mathrm{CO}_{3}^{2-}\right]$. It should also be noted, that in the real ocean $\left[\mathrm{CO}_{3}^{2-}\right]$ and $\mathrm{pH}$ covary linearly across the relevant $\mathrm{pH}$ range.
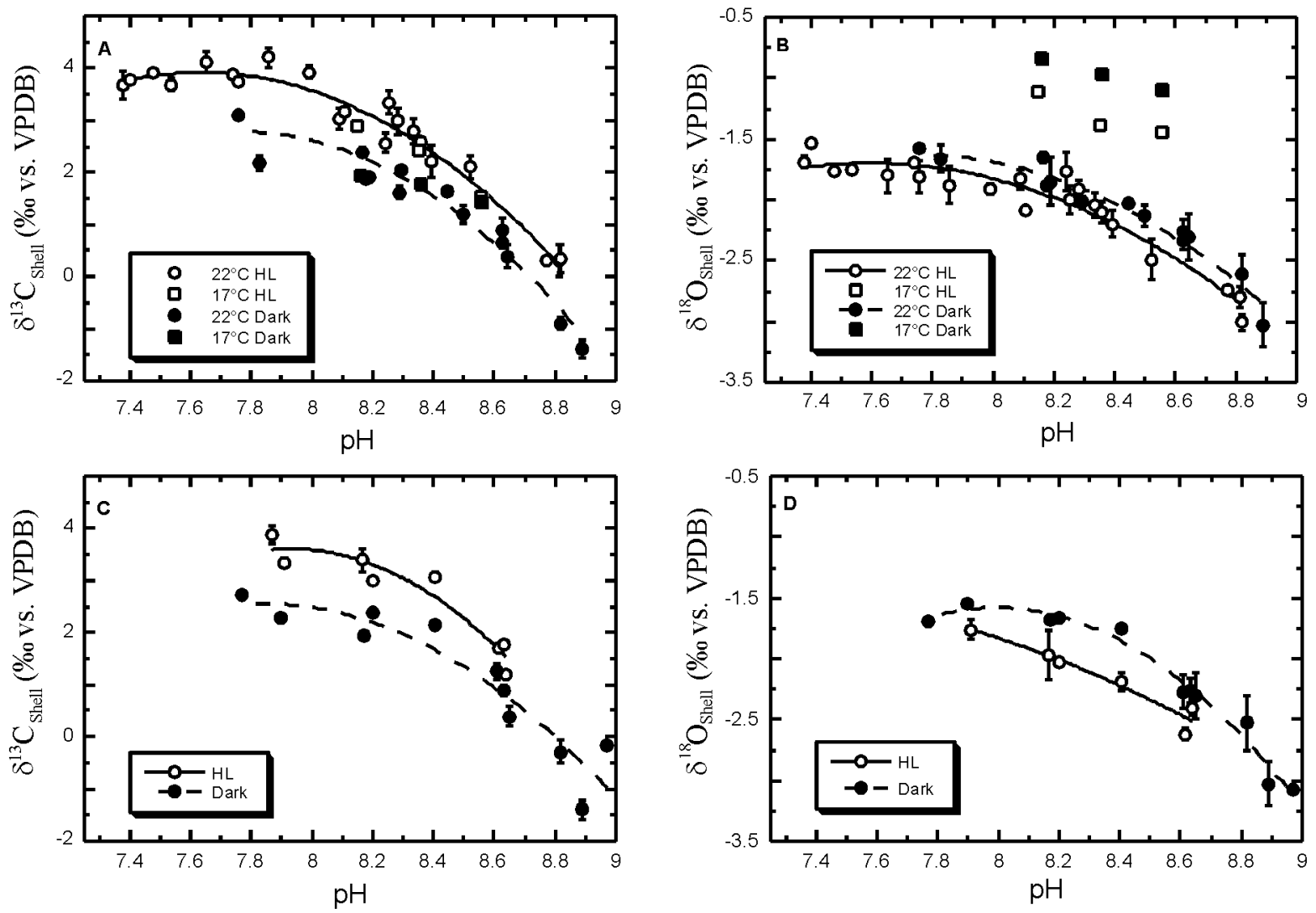

Fig. 10. Effect of $\mathrm{pH}$ on the $\delta^{13} \mathrm{C}$ and $\delta^{18} \mathrm{O}$ values of Orbulina universa shell calcite under constant alkalinity (a and b) and constant $\Sigma \mathrm{CO}_{2}$ (c and d). Circles indicate specimens grown at $22^{\circ} \mathrm{C}$ and squares indicate specimens grown at $17^{\circ} \mathrm{C}$. Open symbols are mean values of specimens grown under high light (HL), closed symbols are specimens grown in the dark. Plotted data are group mean values \pm 1 s.d. Lines are linear regressions fitted to the data. 


\section{Impact of Respired $\mathrm{CO}_{2}$}

Because isotopes are conserved in metabolism, the extent of ${ }^{13} \mathrm{C}$ depletion of respired $\mathrm{CO}_{2}$ must reflect the $\delta^{13} \mathrm{C}$ of the carbon source and the carbon budget of the consumer. Thus, the $\delta^{13} \mathrm{C}$ of respired $\mathrm{CO}_{2}$ depends on the $\delta^{13} \mathrm{C}$ value of the food source and the $\delta^{13} \mathrm{C}_{\text {org }}$ of the foraminifer. The following mass balance calculation may be considered:

$\delta^{13} \mathrm{C}_{\text {source }}=\left[\mathrm{r} \bullet \delta^{13} \mathrm{C}_{\text {foram }}\right]+\left[(1-\mathrm{r}) \bullet \delta^{13} \mathrm{C}_{\text {resp }}\right]$

where $r$ is the fraction of carbon retained by the foraminifer. Rearranged:

$\delta^{13} C_{\text {resp }}=\left(\delta^{13} C_{\text {source }}-\left[r \bullet \delta^{13} C_{\text {foram }}\right]\right) /(1-r)$

For symbiont bearing species it was demonstrated that a substantial fraction (denoted s) of the host's carbon is derived from the symbionts, probably translocated during the night when the symbionts are retracted in the shell (Bemis pers. comm.). Thus for $O$. universa the equation must be expanded: $\delta^{13} \mathrm{C}_{\text {resp }}=\left(\left[\mathrm{s} \bullet \delta^{13} \mathrm{C}_{\text {symbiont }}\right]+\left[1-\mathrm{s} \bullet \delta^{13} \mathrm{C}_{\text {food }}\right]\right.$
$\left.-\left[\mathrm{r} \bullet \delta^{13} \mathrm{C}_{\text {foram }}\right]\right) /(1-\mathrm{r})$

$\delta^{13} \mathrm{C}$ of the artemia, the host and the symbionts is a function of their biochemical composition, especially of the lipid content. Corrected for the carapace, that is discarded after digestion, the $\delta^{13} \mathrm{C}$ value a Great Salt Lake artemia nauplii (GSL) is $-15 \%$. The $\delta^{13} \mathrm{C}_{\text {org }}$ of $O$. universa and G. bulloides fed GSL artemia is $-17.4 \%$ and $-18.5 \%$ respectively (Uhle unpubl. results). Based on compound specific isotope analysis (Table 2 ) and the assumption that lipids are $5 \%$ depleted compared to the average $\delta^{13} \mathrm{C}$ of symbiont organic matter, a $\delta^{13} \mathrm{C}_{\text {symbiont }}$ of $-24 \%$ can be estimated (Schouten pers. comm.). If we further assume that $56 \%$ of the carbon taken up by $O$. universa originates from the GSL-artemia and that the rest is derived from the symbionts (Bemis pers comm) and that only one tenth of the carbon taken up is retained, the $\delta^{13} \mathrm{C}$ of the respired $\mathrm{CO}_{2}$ is $-19.1 \%$ and $-14.6 \%$ for $O$. universa and G. bulloides respectively (Table 3). Bemis (unpubl data) determined that the $\delta^{13} \mathrm{C}_{\text {org }}$ of $O$. universa fed artemia nauplii of a San Francisco Bay (SFB) strain was $-18.6 \%$, while the artemia were on the average $-20.4 \%$ o (corrected for the carapace). The $\delta^{13} \mathrm{C}$ of the respired $\mathrm{CO}_{2}$ under these conditions is $-22.4 \%$ o (Table 3). Unfortunately, we have no data for $G$. bulloides fed SFB artemia.

Respiring organisms consume ${ }^{16} \mathrm{O}^{16} \mathrm{O} 10$ to $20 \%$ more rapidly than ${ }^{18} \mathrm{O}^{16} \mathrm{O}$. With respect to
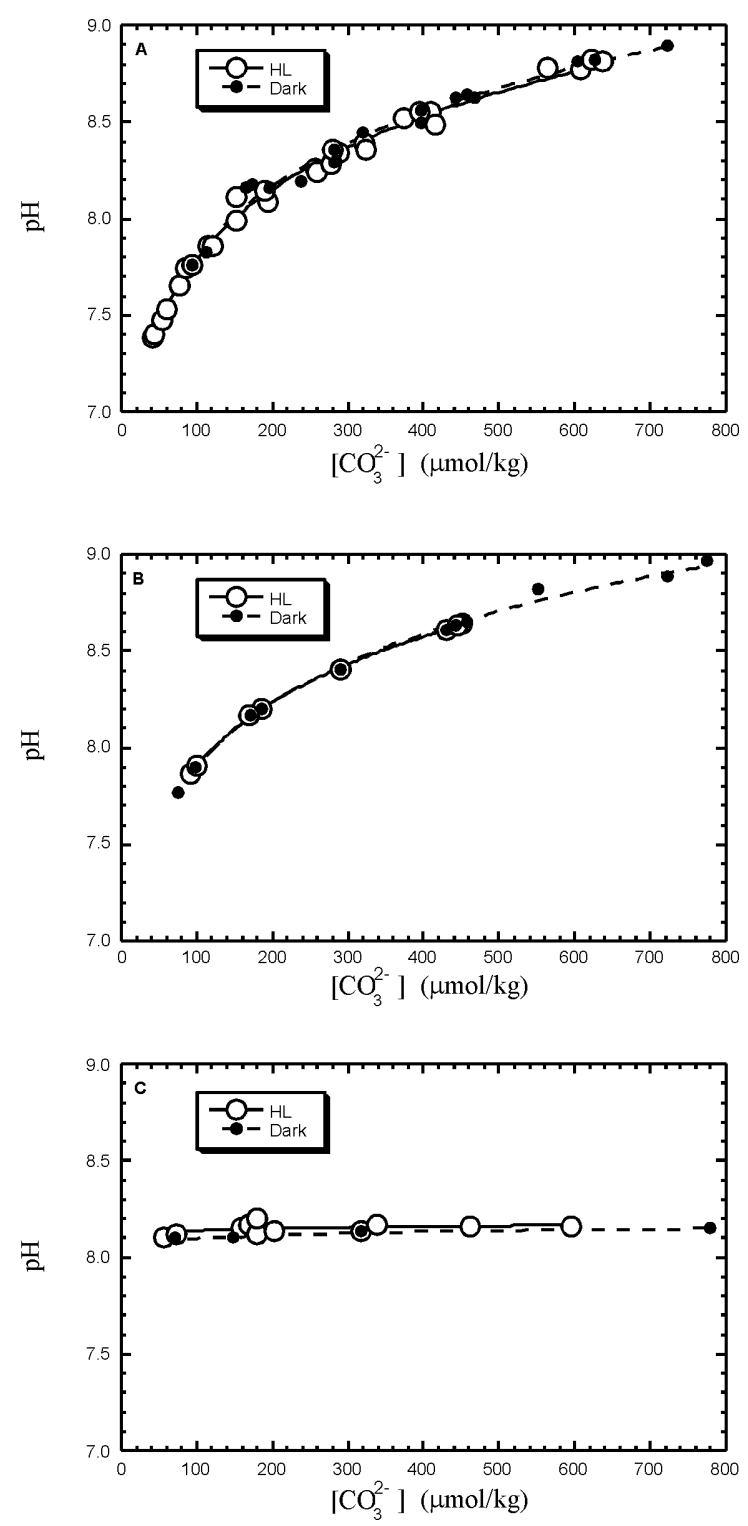

Fig. 11. Relationship between $\left[\mathrm{CO}_{3}^{2-}\right]$ and $\mathrm{pH}$ at constant alkalinity (a), constant $\Sigma \mathrm{CO}_{2}$ (b) and, constant $\mathrm{pH}$ (c). 
the metabolic fractionation during respiration a fractionation factor of 1.016 has been proposed for oxygen (Lane and Dole 1956). Others (Kiddon et al. 1993), measured a respiratory isotope effect between $14 \%$ o to $26 \%$ o for seven representative unicellular marine organisms and estimate that the average fractionation of the dominant marine respirers is about $20 \pm 3 \%$ o. A generalized respiration equation is given by:

$$
\mathrm{CH}_{2} \mathrm{O}+\mathrm{O}_{2} \rightarrow \mathrm{CO}_{2}+\mathrm{H}_{2} \mathrm{O}
$$

\begin{tabular}{|c|c|}
\hline "free sterols" & $\delta^{13} \mathrm{C}$ \\
\hline cholest-5,22-dienol & $-29.5 \% 0 \pm 0.2 \%$ \\
\hline cholesterol (=cholest-5-enol) & $-28.7 \% \circ \pm 0.2 \%$ \\
\hline ergosta-5,22-dienol & $-29.1 \% 0 \pm 0.1 \%$ \\
\hline \multirow[t]{2}{*}{ ergosta-5,24(28)-dienol } & $(-24.9 \% \circ \pm 0.1 \% o)$ \\
\hline & ca. $-29 \%$ \\
\hline
\end{tabular}

Table 2. Stable carbon isotope values of dominant free sterols. Ergosta-5,24(28)-dienol was not used for the determination of the average $\delta^{13} \mathrm{C}$. We believe that the much heavier isotope signature of this compound originates from heterotrophic "swarmers".

\begin{tabular}{lcc}
\hline \multirow{2}{*}{ artemia strain } & \multicolumn{2}{c}{$\delta^{13} \mathrm{Cresp}(\%)$} \\
& O. universa & G. bulloides \\
\hline GSL (-15\%o) & -19.1 & -14.6 \\
SFB $(-20.4 \%)$ & -22.4 & n.a. \\
\hline
\end{tabular}

Table 3. Calculated $\delta^{13} \mathrm{C}$ of respired $\mathrm{CO}_{2}$ for a symbiont bearing and a symbiont barren species fed two different strains of artemia (GSL = Great Salt Lake; SFB = San Francisco Bay).
If we assume a fractionation of $20 \%$ during respiration and that the $\delta^{18} \mathrm{O}$ of $\mathrm{O}_{2}$ is $-0.45 \%$ vs. VSMOW (equivalent to $\mathrm{H}_{2} \mathrm{O}$ ) and if we further assume that the $\delta^{18} \mathrm{O}$ of the combined host/symbiont organic matter is $28 \%$ (Swart 1983) and that $\mathrm{CO}_{2}$ and $\mathrm{H}_{2} \mathrm{O}$ maintain their characteristic fractionation of 1.0412 at $25{ }^{\circ} \mathrm{C}$ (Friedman and O'Neil 1977), respiration may produce a pool of ${ }^{18} \mathrm{O}$-depleted $\mathrm{CO}_{2}$ and cell $\mathrm{H}_{2} \mathrm{O}$. However, due to the large cell water reservoir and the large water fluxes across the membrane (according to McConnaughey (1989a) 6 orders of magnitude larger than photosynthetic or respiration fluxes) the $\delta^{18} \mathrm{O}$ of the cell water quickly returns to $-0.45 \%$. Thus, although respired $\mathrm{CO}_{2}$ can be $13 \%$ o depleted compared to $\delta^{18} \mathrm{O}$ of bulk $\mathrm{CO}_{2}$, the fast isotope exchange with cell water may completely cancel this offset. However, once converted to $\mathrm{CO}_{3}^{2-}$ a part of the signal may be preserved due to the slow exchange of oxygen isotopes between dissolved $\mathrm{CO}_{3}^{2-}$ and $\mathrm{H}_{2} \mathrm{O}$ (McConnaughey 1989a).

In summary, incorporation of respired $\mathrm{CO}_{2}$ can significantly lower shell $\delta^{13} \mathrm{C}$ but does probably not affect $\delta^{18} \mathrm{O}$. For example, Spero and Lea (1996) demonstrated that G. bulloides, when fed SFB artemia is ca. $0.5 \%$ o depleted in ${ }^{13} \mathrm{C}$ compared to specimens fed GSL artemia but that shell $\delta^{18} \mathrm{O}$ was unaffected. Thus, incorporation of respired $\mathrm{CO}_{2}$ lowers shell $\delta^{13} \mathrm{C}$ but the effect is relatively small compared to the ca. 3 times larger photosynthetic effect that has been determined for $O$. universa and G. sacculifer. However, the calculations by Spero and Lea (1996) are based on the isotopic difference of the food source. In the following we will use the calculated isotopic difference in the respired $\mathrm{CO}_{2}$ (Table 3). If all respired $\mathrm{CO}_{2}$ would be incorporated into the shell (100\% efficiency), the shell $\delta^{13} \mathrm{C}$ difference of specimens fed SFB or GSL artemia should be $3.3 \%$, i.e. reflect the full difference in the carbon isotopic composition of respired $\mathrm{CO}_{2}$. Since the difference in shell $\delta^{13} \mathrm{C}$ of $G$. sacculifer fed SFB and GSL artemia, is on the average only $0.55 \%$ (Bijma, Spero and Lea unpubl. results) it can be calculated that the impact of respiration on the shell isotopic value is ca. $17 \%$. Consequently, with an efficiency of $17 \%$, respiration can lower the shell isotopic 
composition by 3.2 to $3.8 \%$, respectively, when fed GSL and SFB artemia.

\section{Symbiont Effect}

Our experimental results have separated the influence of symbiont photosynthesis from the influence of the carbonate chemistry on the shell isotopic composition calcification. The observed ${ }^{13} \mathrm{C}$-enrichment and ${ }^{18} \mathrm{O}$-depletion in HL O. universa relative to specimens maintained in the dark are clearly a function of symbiont photosynthesis and have been reported before. With respect to ${ }^{13} \mathrm{C}$-enrichment, a mechanism has been proposed whereby RUBISCO preferentially removes ${ }^{12} \mathrm{CO}_{2}$ during photosynthesis and subsequently enriches the calcifying environment with ${ }^{13} \mathrm{C}$ (Spero 1992; Spero and DeNiro 1987; Spero and Lea 1993; Spero et al. 1991; Spero and Williams 1989).

Because it is generally assumed that photosynthesis per se does not affect the $\delta^{18} \mathrm{O}$ of the photosynthate nor that of the residual $\mathrm{H}_{2} \mathrm{O}-\mathrm{CO}_{2}-\mathrm{HCO}_{3}^{-}$pool (Swart 1983), ${ }^{18} \mathrm{O}$-depletion in symbiotic systems were tentatively explained as the result of light-enhanced calcification rates (Bouvier-Soumagnac et al. 1986; Spero 1992; Spero and Lea 1993). However, as discussed before, our data suggest that calcification rate may not explain the oxygen isotope fractionation observed in this study. In the rest of this section we propose an alternative mechanism based on local $\mathrm{pH}$ changes induced by carbon fixation of the symbionts.

Since the symbiotic algae increase the $\mathrm{pH}$ of the foraminiferal microenvironment to as much as 8.8 during photosynthesis (Jørgensen et al. 1985), the local $\left[\mathrm{CO}_{3}^{2-}\right]$ will be elevated as well (WolfGladrow et al.1999). The observed differences in $\delta^{18} \mathrm{O}$ between $\mathrm{HL}$ and dark range from $0.35 \%$ or O. universa (Spero 1992) to $0.63 \%$ o for G. sacculifer (Spero and Lea 1993). If we assume that this difference is solely due to the symbiont induced shift in the ambient carbonate chemistry, and further that the $\delta^{18} \mathrm{O} /\left[\mathrm{CO}_{3}^{2-}\right]$ and a $\delta^{13} \mathrm{C} /\left[\mathrm{CO}_{3}^{2-}\right]$ slopes are $-0.002 \%$ and $-0.0065 \%$ o respectively (Table 1 ), a simultaneous shift of $1.1 \%$ and $2.0 \%$ o towards more negative $\delta^{13} \mathrm{C}$ values at HL can be calculated for $O$. universa and G. sacculifer, respectively. On the contrary, we found a positive shift of $1.1 \%$ for $O$. universa and others have shown that compared to specimens grown in the dark, $\delta^{13} \mathrm{C}$ of $O$. universa and $G$. sacculifer kept above saturation light levels, is enriched by $1.7 \%$ (Spero 1992) and 1.4\%o (Spero and Lea 1993), respectively. Consequently, if we take the kinetic effect on $\delta^{13} \mathrm{C}$ and $\delta^{18} \mathrm{O}$ (induced by local changes in the carbonate chemistry) into account, we have to invoke an additional mechanism to explain a concomitant enrichment in $\delta^{13} \mathrm{C}$ between 2.2 to $2.8 \%$ for $O$. universa and even $3.4 \%$ for $G$. sacculifer.

RUBISCO has always been the first choice to explain shell enrichment in the light. However, this mechanism requires that sufficient $\mathrm{CO}_{2}$ is available to enrich the residual $\mathrm{CO}_{2}$ pool or, if $\mathrm{HCO}_{3}^{-}$is the carbon source, that not all $\mathrm{CO}_{2}$ (once converted from $\mathrm{HCO}_{3}{ }^{-}$) if fixed by RUBISCO and that some diffuses to the site of calcification. Numerical experiments (Wolf-Gladrow et al. 1999) have demonstrated that the symbionts are $\mathrm{CO}_{2}$ limited, even at low photosynthetic rates, and therefore use $\mathrm{HCO}_{3}{ }^{-}$as their main carbon source. These experiments have also demonstrated that a steep $\mathrm{CO}_{2}$ gradient exists between the shell surface and the symbiont halo, probably acting as an efficient barrier against $\mathrm{CO}_{2}$ diffusion towards the shell. As the $\mathrm{HCO}_{3}^{-}$pool is very large and hardly affected by photosynthetic carbon fixation, and the $\delta^{13} \mathrm{C}$ of $\mathrm{HCO}_{3}^{-}$ is very close to the $\delta^{13} \mathrm{C}$ of $\Sigma \mathrm{CO}_{2}$, we argue that RUBISCO is probably not responsible for the HL:dark shift. This conclusion is supported by experiments carried out at constant $\mathrm{pH}$ (Fig. 3e). As $\mathrm{CO}_{2}$ availability increases, shells get lighter instead of heavier, suggesting that enzyme mediated ${ }^{13} \mathrm{C}$ enrichment of the ambient environment plays a subordinate role, if at all.

As an alternative hypothesis to explain the observed positive shift between the HL and dark experiments we propose scavenging of respired ${ }^{12} \mathrm{CO}_{2}$ by the symbionts. In the previous section we have shown that respired $\mathrm{CO}_{2}$ can lower shell $\delta^{13} \mathrm{C}$ by 3.2 to $3.8 \%$ (depending on the food source), enough to explain the required enrichment in the light of up to $3.4 \%$. The decrease in shell $\delta^{13} \mathrm{C}$ with increasing $\left[\mathrm{CO}_{2} \mathrm{aq}\right]$ at constant $\mathrm{pH}$ can now be explained by a decrease in the scavenging efficiency of respired $\mathrm{CO}_{2}$ as bulk $\mathrm{CO}_{2}$ increases. Thus 
scavenging of light respired $\mathrm{CO}_{2}$ can explain the observed difference between the HL and dark results and the trend noticed in the constant $\mathrm{pH}$ experiments. In addition, effective scavenging of light respired $\mathrm{CO}_{2}$ could also explain the very negative value of the symbiont organic matter $(-24 \%)$ even though $\mathrm{HCO}_{3}^{-}$is the main carbon source.

The proposed mechanism of $\mathrm{CO}_{2}$ scavenging can operate only if metabolic $\mathrm{CO}_{2}$ diffuses freely through the membrane of the host and is not stored in an internal inorganic carbon pool. The pulsechase experiments demonstrate that such a pool is not present in $O$. universa (Fig. 6).

\section{Proposed Fractionation Mechanisms}

Based on our experiments we propose that 3 fractionation mechanisms can be recognized:

1) $\mathrm{pH}$ or $\left[\mathrm{CO}_{3}^{2-}\right]$ dependent kinetic fractionation of both carbon and oxygen stable isotopes.

2) Incorporation of respired $\mathrm{CO}_{2}$ depleted in ${ }^{13} \mathrm{C}$. In symbiont bearing species in the light.

3) Enrichment of the calcifying environment with ${ }^{13} \mathrm{C}$ (compared to the dark) due to scavenging of light respired $\mathrm{CO}_{2}$ (RUBISCO related effects are probably of minor importance).

\section{Light/dark Shift of Shell Stable Isotopes}

In all experiments $\left(\mathrm{Calk}_{\mathrm{t}}, \mathrm{C} \Sigma \mathrm{CO}_{2}\right.$ and $\left.\mathrm{CpH}\right)$, the $\delta^{18} \mathrm{O}$ value of shells grown in the light is depleted compared to shells kept in the dark. Such a decrease in shell $\delta^{18} \mathrm{O}$ with increasing irradiance has been documented before for $G$. sacculifer and O. universa (Spero and Lea 1993). Because metabolic processes do not directly affect the $\delta^{18} \mathrm{O}$ signal of the shell, we argue that an increase of $\mathrm{pH}$ or $\left[\mathrm{CO}_{3}^{2-}\right]$ in the calcifying environment, either due to bulk carbonate chemistry changes or induced by photosynthesis, depletes shells in ${ }^{18} \mathrm{O}$ via mechanism 1.

The enrichment of $\delta^{13} \mathrm{C}$ in the light observed in all experiments $\left(\mathrm{Calk}_{\mathrm{t}}, \mathrm{C} \Sigma \mathrm{CO}_{2}\right.$ and $\left.\mathrm{CpH}\right)$ must be explained in terms of competing processes. First is the depletion of shell $\delta^{13} \mathrm{C}$ kinetically driven by the photosynthetically raised $\mathrm{pH}$ (mechanism 1). Secondly, Zeebe et al. (1999) have demonstrated that more respired $\mathrm{CO}_{2}$ gets incorporated into the shell at higher $\mathrm{pH}$. Hence, because the $\delta^{13} \mathrm{C}$ of respired $\mathrm{CO}_{2}$ is significantly depleted compared to bulk $\mathrm{CO}_{2}$, the fractional change of metabolic versus bulk $\mathrm{CO}_{2}$ incorporation into the shell will reinforce the depletion. In addition, a higher light- compared to dark-respiration rate of the symbionts (Weger et al. 1989) may deplete the calcifying environment even more under HL. The enrichment of shell $\delta^{13} \mathrm{C}$ is dictated by very effective scavenging of light respired $\mathrm{CO}_{2}$ (mechanism 3). A decline in the scavenging efficiency with increasing $\left[\mathrm{CO}_{2} \mathrm{aq}\right]$ could explain the trend in the constant $\mathrm{pH}$ experiments (more respired $\mathrm{CO}_{2}$ escapes photosynthetic fixation and gets incorporated into the shell).

The question may be raised why scavenging of respired $\mathrm{CO}_{2}$ dominates the impact of kinetic fractionation (mechanism 1 ) on $\delta^{13} \mathrm{C}$ signal but not on the $\delta^{18} \mathrm{O}$ signal? The reason is twofold. First, theoretical considerations require that the impact of kinetic fractionation on ${ }^{13} \mathrm{C} /{ }^{12} \mathrm{C}$ is half that of ${ }^{18} \mathrm{O} /{ }^{16} \mathrm{O}$ (McCrea 1950). Second, the relative depletion of respired $\mathrm{CO}_{2}$ with respect to ${ }^{13} \mathrm{C}$ is large whereas the depletion in ${ }^{18} \mathrm{O}$ may be lost quickly due to the large water reservoir compared to $\Sigma \mathrm{CO}_{2}$ and the fast exchange reactions.

\section{Decoupling of the $\delta^{13} \mathrm{C} /\left[\mathrm{CO}_{3}^{2-}\right]$ Relationship at High $\left[\mathrm{CO}_{2} \mathrm{aq}\right]$ in the Light}

A change in the scavenging efficiency may also explain the "plateau" or the decrease in $\delta^{13} \mathrm{C}$ towards lower $\left[\mathrm{CO}_{3}^{2-}\right]$ in the constant alkalinity experiments (Fig. 3a). At higher $\left[\mathrm{CO}_{2} \mathrm{aq}\right]$ (i.e. lower $\left[\mathrm{CO}_{3}^{2-}\right]$ ), scavenging of metabolic $\mathrm{CO}_{2}$ may become less effective and consequently an increasing portion of light respired $\mathrm{CO}_{2}$ is incorporated into the shell. Again, the opposing affect of RUBISCO at high $\left[\mathrm{CO}_{2} \mathrm{aq}\right]$, i.e. the enrichment of the ambient $\Sigma \mathrm{CO}_{2}$ with ${ }^{13} \mathrm{C}$ apparently plays a subordinate role. As noted before is the photosynthetic assimilation of carbon strongly $\mathrm{CO}_{2}$ limited (WolfGladrow et al. 1999). Apparently, even at the maximum $\mathrm{PCO}_{2}$ reached in the constant alkalinity experiments (ca. $1900 \mu \mathrm{atm}$.) the symbionts are still $\mathrm{CO}_{2}$ limited. In seperate experiments (Spero, Bijma and Lea unpubl results), $\mathrm{PCO}_{2}$ was varied between $1400 \mu \mathrm{atm}$ and more than $8000 \mu \mathrm{atm}$. The results 
(not shown here) support the hypothesis that the decrease in shell $\delta^{13} \mathrm{C}$ in the light should be explained in terms of a reduction in the scavenging efficiency and that RUBISCO is of secondary importance. The reason that the $\delta^{18} \mathrm{O}$ signal under $\mathrm{HL}$ is not decoupled from $\left[\mathrm{CO}_{3}^{2-}\right]$ at high $\mathrm{PCO}_{2}$ (Fig. 3b) is because $\delta^{18} \mathrm{O}$ of metabolic $\mathrm{CO}_{2}$ and bulk $\mathrm{CO}_{2}$ are probably not much different. Consequently, changes in the scavenging efficiency do not effect shell $\delta^{18} \mathrm{O}$.

\section{Conclusions}

1) Shifts in $\mathrm{pH}$ (and for natural sea water in $\left[\mathrm{CO}_{3}^{2-}\right]$ ) have a significant impact on foraminiferal shell $\delta^{13} \mathrm{C}$ and $\delta^{18} \mathrm{O}$.

2) Both symbiotic (Orbulina universa) and nonsymbiotic (Globigerina bulloides) species display this effect. Therefore, we hypothesize that this effect is common among other species.

3) The effect is species dependent and based on a combination of kinetic and metabolic fractionation processes.

4) $\mathrm{A} \mathrm{pH} /$ carbonate isotope effect has important implications for the interpretation of stable isotope data in the fossil record. Shells calcifying during cold climate periods record isotopic signatures that cannot be interpreted directly using present-day relationships (cf. Lea et al. this volume)

5) Because the carbonate ion effect appears to be a major factor influencing the foraminiferal isotope record, calibration of the response in each of the major paleoceanographic species is a necessary next step towards fully understanding and utilizing the oceanic isotopic record.

\section{Acknowledgments}

We thank the staff of the Wrigley Environmental Science Center and E. Kincaid, C. Hamilton, J. Dailey, E. Komsky, T. Mashiotta, M. Uhle, A. Sanyal, D. Chan, E. Mochon, M. Cramer and V. Hubner for their help in the field. Thanks go to $S$. Schouten for the compound specific isotope analysis and to $\mathrm{W}$. Berger and an anonymous reviewer for many helpful suggestions. This research was funded by the Deutsche Forschungsgemeinschaft (Sonderforschungsbereich 261 at Bremen University, contribution 203) and the Program for the Advancement of Special Research Projects at the Alfred Wegener Institute, Germany (JB) and by the US National Science Foundation (HJS and DWL). Data are available under www.pangaea.de/Projects/SFB261.

\section{References}

Bard E, Arnold M, Duprat J, Moyes J, Duplessy JC (1987) Reconstruction of the last deglaciation: deconvolved records of $\delta^{18} \mathrm{O}$ profiles, micropaleontological variations and accelerator mass spectrometric C-14 dating. Clim Dyn 1987(1): 101-112

Bé AWH (1979) Planktonic foraminifera: Ultrastructural changes caused by calcification during gametogenesis in Globigerinoides sacculifer (Brady). Geol Soc Am Abstracts with programs 11: 385-386

Bé AWH (1980) Gametogenic calcification in a spinose planktonic foraminifer, Globigerinoides sacculifer (Brady). Mar Micropaleontol 5: 283-310

Bé AWH (1982) Biology of planktonic foraminifera. In: Broadhead TW (ed) Foraminifera: notes for a short course. Department of Geological Sciences, Knoxville, Tennessee, pp 51-92

Bé AWH, Anderson OR (1976) Gametogenesis in planktonic foraminifera. Science 192(1-3): 890-892

Bé AWH, Anderson OR, Faber WW Jr (1983) Sequence of morphological and cytoplasmic changes during gametogenesis in the planktonic foraminifer Globigerinoides sacculifer (Brady). Micropaleontology 29(3): 310-325

BéAWH, Hemleben C, Anderson OR, Spindler M, (1979) Chamber formation in planktonic foraminifera. Micropaleontology 25(3): 294-306

Bé AWH, Hemleben C, Anderson OR, Spindler M, Hacunda J, Tuntivate-Choy S (1977) Laboratory and field observations of living planktonic foraminifera. Micropaleontology 23(2): 155-179

Bé AWH, Hutson WH (1977) Ecology of planktonic foraminifera and biogeographic patterns of life and fossil assemblages in the Indian Ocean. Micropaleontology 23(4): 369-414

Bé AWH, Tolderlund DS (1971) Distribution and ecology of living planktonic foraminifera in surface waters of the Atlantic and Indian Oceans. In: Funnel BM, Riedel WR (eds) The micropaleontology of oceans. Cambridge Univ Press, pp 105-149

Bemis BE, Spero HJ, Bijma J, Lea DW (1998) Reevaluation of the oxygen isotopic composition of planktonic foraminifera: experimental results and revised paleotemperature equations. Paleoceano- 
graphy 13(2): 150-160

Berger WH (1979) Stable isotopes in foraminifera. In: Lipps JH, Berger WH, Buzas MA, Douglas RG, Ross CA (eds) Foraminiferal ecology and paleoecology (SEPM short course No. 6). Society of Economic Paleontologists and Mineralogists, Houston, Texas, pp 156-197

Berger WH, Killingley JS, Vincent E (1978) Stable isotopes in deep-sea carbonates: Box Core ERDC-92 west equatorial Pacific. Oceanol Acta 1(2): 203-216

Berner RA (1994) Geocarb II: A revised model of Atmospheric $\mathrm{CO}_{2}$ over Phanerozoic time. Amer J Sci 294: 56-91

Bijma J, Erez J, Hemleben C (1990) Lunar and semi-lunar reproductive cycles in some spinose planktonic foraminifers. J Foram Res 20(2): 117-127

Bijma J, Hemleben C, Huber BT, Erlenkeuser H, Kroon D (1998) Experimental determination of the ontogenetic stable isotope variability in two morphotypes of Globigerinella siphonifera (d'Orbigny). Mar Micropaleontol 35: 141-160

Bouvier-Soumagnac Y, Duplessy JC (1985) Carbon and oxygen isotopic composition of planktonic foraminifera from laboratory culture, plankton tows and recent sediment: Implications for the reconstruction of paleoclimatic conditions and of the global carbon cycle. J Foram Res 15(4): 302-320

Bouvier-Soumagnac Y, Duplessy JC, Bé AWH (1986) Isotopic composition of a laboratory cultured planktonic foraminifer Orbulina universa . Implications for paleoclimatic reconstructions. Oceanol Acta 9(4): 519-522

Boyle EA (1990) Quaternary deepwater paleoceanography. Science 249(4971): 863-870

Broecker WS (1971) A kinetic model for the chemical composition of sea water. Quat Res 1: 188-207

Broecker WS (1973) Factors controlling $\mathrm{CO}_{2}$ content in the oceans and atmosphere. Carbon and the biosphere: AEC symposium 30: 32-50

Broecker WS (1981) Glacial to interglacial changes in ocean and atmosphere chemistry. In: Berger A (ed) Climatic variations and variability: Facts and Theories. Reidel, Dordrecht, pp 109-120

Broecker WS, Maier-Reimer E (1992) The influence of air and sea exchange on the carbon isotope distribution in the sea. Global Biogeochem Cycles 6(3): 315-320

Broecker WS, Peng T-H (1982) Tracers in the Sea. Lamont-Doherty Geological Observatory, Columbia University, Palisades, New York, pp 1-690

Broecker WS, Van Donk J (1970) Insolation changes, ice volumes, and the O18-record in deep-sea cores.
Reviews of Geophysics and Space Physics 8(1): 169-198

Buchardt B, Hansen HJ (1977) Oxygen isotope fractionation and algal symbiosis in benthic foraminifera from the Gulf of Elat, Israel. Bull Geol Soc Denmark 26: 185-194

Charles CD, Fairbanks RG (1990) Glacial to interglacial changes in the isotopic gradients of Southern Ocean surface water. In: Bleil U, Thiede J (eds) Geological history of the polar oceans: Arctic versus Antarctic. NATO ASI Series C308, Kluwer, Dordrecht, pp 519-538

Charles CD, Fairbanks RG (1992) Evidence from Southern Ocean sediments for the effect of North Atlantic deep-water flux on climate. Nature 355: 416-419

Charles CD, Wright JD, Fairbanks RG (1993) Thermodynamic influences on the marine carbon isotope record. Paleoceanography 8: 691-697

Cummings CE, McCarty HB (1982) Stable carbon isotope ratios in Astrangia danae: evidence for algal modification of carbon pools used in calcification. Geochim Cosmochim Acta 46(6): 1125-1129

Curry WB, Matthews RK (1981a) Equilibrium ${ }^{18} \mathrm{O}$ fractionation in small size fraction planktic foraminifera: Evidence from recent Indian Ocean sediments. Mar Micropaleontol 6: 327-337

Curry WB, Matthews RK (1981b) Paleo-oceanographic utility of oxygen isotopic measurements on planktic foraminifera: Indian Ocean core-top evidence. Palaeogeogr Paleoclimatol Palaeoecol 33 (13): 173-192

Duplessy JC (1978) Isotope studies. In: Gribbin J (ed) Climatic change. Cambridge University Press, Cambridge, pp 46-67

Duplessy JC, Bé AWH, Blanc PL (1981) Oxygen and carbon isotopic composition and biogeographic distribution of planktonic foraminifera in the Indian Ocean. Palaeogeogr Paleoclimatol Palaeoecol 33 (1-3): 9-46

Duplessy JC, Lalou C, Vinot-Bertouille AC (1970) Differential isotopic fractionation in benthic foraminifera and paleotemperature, reassesed. Science 168: 250-251

Emiliani C (1954) Depth habitats of some species of pelagic foraminifera as indicated by oxygen isotope ratios. Amer J Sci 252: 149-158

Epstein S, Buchsbaum R, Lowenstam HA, Urey HC (1951) Carbonate-water isotopic temperature scale. Geol Soc Amer Bull 62: 417-426

Epstein S, Buchsbaum R, Lowenstam HA, Urey HC (1953) Revised carbonate-water isotopic temperature scale. Geol Soc Amer Bull 64: 1315-1325 
Erez J (1978a) The influence of differential production and dissolution of the stable isotope composition of planktonic foraminifera. Ph D Thesis, Woods HoleMIT joint program, pp 1-119

Erez J (1978b) Vital effect on stable-isotope composition seen in foraminifera and coral skeletons. Nature 273(5659): 199-202

Erez J, Luz B (1983) Experimental paleotemperature equation for planktonic foraminifera. Geochim Cosmochim Acta 47(6): 1025-1031

Fairbanks RG (1989) A 17,000-year glacio-eustatic sea level record: Influence of glacial melting rates on the Younger Dryas event and deep-ocean circulation. Nature 342: 637-642

Fairbanks RG, Charles CD, Wright JD (1992) Origin of global meltwater pulses. In: Taylor RE, Long A, Kra RS (eds) Radiocarbon after four decades. Springer, Berlin Heidelberg New York, pp 473-500

Fairbanks RG, Sverdlove MS, Free R, Wiebe PH, Bé AWH (1982) Vertical distribution and isotopic fractionation of living planktonic foraminifera from the Panama Basin. Nature 298: 841-844

Fairbanks RG, Wiebe PH, Bé AWH (1980) Vertical distribution and isotopic composition of living planktonic foraminifera in the western north Atlantic. Science 207: 61-63

Farquhar GD, O'Leary MH, Berry JH (1982) On the relationship between carbon isotope discrimination and the intercellular carbon dioxide concentration in leaves. Aust J Plant Physiol 9: 121-137

Friedman I, O'Neil JR (1977) Compilation of stableisotope fractionation factors of geochemical interest, Data of Geochemistry. Geol Surv Prof Pap, Washington

Goreau TF (1963) Calcium carbonate deposition by coralline algae and corals in relation to their roles as reef builders. Ann Ny Acad Sci 109: 127-167

Goreau TJ (1977) Coral skeletal chemistry: physiological and environmental regulation of stable isotopes and trace metals in montastrea annularis. Proc Roy Soc London, Ser B 196: 291-315

Grotzinger JP, Kasting JF (1993) New Constraints on Precambrian ocean composition. J Geol 101: 235-243

Hemleben C, Spindler M (1983) Recent advances in research on living planktonic foraminifera. Utrecht Micropaleontol Bull 30: 141-170

Hemleben C, Spindler M, Anderson OR (1989) Modern planktonic foraminifera. Springer, Berlin Heidelberg New York, pp 1-363

Hemleben C, Spindler M, Breitinger I, Deuser WG (1985) Field and laboratory studies on the ontogeny and ecology of some globorotaliid species from the Sar- gasso Sea off Bermuda. J Foram Res 15(4): 254-272

Hemleben C, Spindler M, Breitinger I, Ott R (1987) Morphological and physiological responses of Globigerinoides sacculifer (Brady) under varying laboratory conditions. Mar Micropaleontol 12(4): 305-324

Hut G (1987) Consultants group meeting on stable isotope reference samples for geochemical and hydrological investigations. Rep to Dir Gen, Int At, Energy Agency, Vienna, pp 1-42

Jørgensen BB, Erez J, Revsbech NP, Cohen Y (1985) Symbiotic photosynthesis in a planktonic foraminifera, Globigerinoides sacculifer (Brady), studied with microelectrodes. Limnol Oceanogr 30(6): 1253-1267

Kahn MI, Williams DF (1981) Oxygen and carbon isotopic composition of living planktonic foraminifera from the northeast Pacific Ocean. Palaeogeogr Palaeoclimatol Palaeoecol 33(1-3): 47-76

Kallel N, Labeyrie LD, Leclerc AJ, Duplessy JC (1988) A deep hydrological front between intermediate and deep-water masses in the glacial Indian Ocean. Nature 333: 651-655

Kiddon J, Bender ML, Orchardo J, Caron DA, Goldmann JC, Dennett M (1993) Isotopic fractionation of oxygen by respiring marine organisms. Global Biogeochem Cycles 7(3): 679-694

Kuile Bt, Erez J, Padan E (1989) Mechanisms for the uptake of inorganic carbon by two species of symbiont-bearing foraminifera. Mar Biol 103: 241-251

Labeyrie LD, Duplessy JC, Blanc PL (1987) Variation in mode of formation and temperature of oceanic deep waters over the past 125,000 years. Nature 327: 477-482

Land LS, Lang JC, Barnes DJ (1977) On the stable carbon and oxygen isotopic composition of some shallow water ahermatypic, scleractinian coral skeletons. Geochim Cosmochim Acta 41: 169-172

Lane GA, Dole M (1956) Fractionation of oxygen isotopes during respiration. Science 123: 574-577

Lea DW, Martin PA, Chan DA, Spero HJ (1995) Calcium uptake and calcification rate in the planktonic foraminifer Orbulina universa. J Foram Res 25(1): 14-23

Lynch-Stieglitz J, Stocker TF, Broecker WS, Fairbanks R (1995) The influence of air-sea exchange on the isotopic composition of oceanic carbon: Observations and modeling. Global Biogeochem Cycles 9(4): 653-665

Mackensen A, Hubberten H-W, Bickert T, Fischer G, Fütterer DK (1993) The $\delta^{13} \mathrm{C}$ in benthic foraminiferal tests of Fontbotia wuellerstorfi (Schwager) relative 
to the $\delta^{13} \mathrm{C}$ of dissolved inorganic carbon in Southern Ocean Deep Water: Implications for glacial ocean circulation models. Paleoceanography 8(5): 587-610

McConnaughey $\mathrm{T}$ (1989a) ${ }^{13} \mathrm{C}$ and ${ }^{18} \mathrm{O}$ isotopic disequilibrium in biological carbonates: II. In vitro simulation of kinetic isotope effects. Geochim Cosmochim Acta 53: 163-171

McConnaughey T (1989b) ${ }^{13} \mathrm{C}$ and ${ }^{18} \mathrm{O}$ isotopic disequilibrium in biological carbonates. I. Patterns. Geochim Cosmochim Acta 53(1): 151-162

McCrea JM (1950) On the isotopic chemistry of carbonates and a paleotemperature scale.Chem Physics 18: 849-857

Mix AC (1987) The oxygen-isotope record of glaciation. In: Ruddiman WF, Wright HEJ (eds) North America and adjacent oceans during the last deglaciation. The Geology of North America. Geol Soc Amer, Boulder, pp 111-135

Mook WG, Bommerson JC, Staverman WH (1974) Carbon isotope fractionation between dissolved bicarbonate and gaseous carbon dioxide. Earth Planet Sci Lett 22: 169-176

Naidu PD, Malmgren BA (1996a) A high-resolution record of late Quaternary upwelling along the Oman Margin, Arabian Sea based on planktonic foraminifera. Paleoceanography 11(1): 129-140

Naidu PD, Malmgren BA (1996b) Relationship between late Quaternary upwelling history and coiling properties of Neogloboquadrina pachyderma and Globigerina bulloides in the Arabian Sea. J Foram Res 26(1): 64-70

Revelle R, Fairbridge RW (1957) Carbonates and carbon dioxide. In: Hedgpeth JW (ed) Treatise on marine ecology and paleoecology, Vol 1, ecology. Geol Soc Amer Mem, pp 239-296

Rozanski K, Araguás-Araguás L, Gonfiantini R (1993) Isotopic Patterns in Modern Global Precipation. Geophys Monogr 78: 1-35

Sanyal A, Hemming NG, Hanson GN, Broecker WS (1995) Evidence for a higher $\mathrm{pH}$ in the glacial ocean from boron isotopes in foraminifera. Nature 373(6511): 234-236

Sautter LR, Thunell RC (1989) Seasonal succesion of planktonic foraminifera: results from four-year time series sediment trap experiment in the northeast Pacific. J Foram Res 19(4): 253-267

Sautter LR, Thunell RC (1991) Planktonic foramini-feral response to upwelling and seasonal hydrographic conditions: sediment trap results from San Pedro Basin, southern California Bight. J Foram Res 21(4): 347-363
Sautter, RL, Sancetta C (1992) Seasonal associations of phytoplankton and planktic foraminifera in an upwelling region and their contribution to the seafloor. Mar Micropaleontol 18: 263-278

Schiebel R, Bijma J, Hemleben C (1997) Population dynamics of the planktic foraminifer Globigerina bulloides from the North Atlantic. Deep-Sea Res 44(9-10): 1701-1713

Schrag DP, Hampt G, Murray DW (1996) Pore fluid constraints on the temperature and oxygen isotope composition of the glacial ocean. Science 272: 1930-1932

Shackleton NJ (1967) Oxygen isotope analysis and Pleistocene temperatures re-assessed. Nature 215: 15-17

Shackleton NJ (1974) Attainment of isotopic equilibrium between ocean water and the benthonic foraminifera genus Uvigerina: isotopic changes in the ocean during the last glacial. In: Labeyrie J (ed) Les méthodes quantitatives d'étude des variations du climat au cours du pléistocène. CNRS, Paris, pp 203-209

Shackleton NJ (1977) Carbon-13 in Uvigerina: Tropical rainforest history and the Equatorial Pacific carbonate dissolution cycles. In: Andersen NR, Malahoff A (eds) The fate of fossil fuel $\mathrm{CO}_{2}$ in the oceans. Plenum, New York, pp 401-427

Shackleton NJ, Wiseman JDH and Buckley HA (1973) Non-equilibrium isotopic fractionation between seawater and planktonic foraminiferal tests. Nature 242: 177-179

Spero HJ (1986) Symbiosis, chamber formation and stable isotope incorporation in the planktonic foraminifer Orbulina universa. $\mathrm{PhD}$ Thesis, Univ California, Santa Barbara, pp 1-222

Spero HJ (1988) Ultrastructural examination of chamber morphogenesis and biomineralization in the planktonic foraminifer Orbulina universa. Mar Biol 99(1): 9-20

Spero HJ (1992) Do planktic foraminifera accurately record shifts in the carbon isotopic composition of seawater $\Sigma \mathrm{CO}_{2}$ ? Mar Micropaleontol 19: 275-285

Spero HJ, Bijma J, Lea DW, Bemis BE (1997) Effect of seawater carbonate concentration of foraminiferal carbon and oxygen isotopes. Nature 390(6659): 497-500

Spero HJ, DeNiro MJ (1987) The influence of symbiont photosynthesis on the $\delta^{18} \mathrm{O}$ and $\delta^{13} \mathrm{C}$ values of planktonic foraminiferal shell calcite. Symbiosis 4: 213-228

Spero HJ, Lea DW (1993) Intraspecific stable isotope variability in the planktic foraminifera Globigerinoides sacculifer: Results from laboratory experiments. Mar Micropaleontol 22(3): 221-234 
Spero HJ, Lea DW (1996) Experimental determination of stable isotope variability in Globigerina bulloides: Implications for paleoceanographic reconstructions. Mar Micropaleontol 28(3-4): 231-246

Spero HJ, Lerche I, Williams DF (1991) Opening the carbon isotope "vital effect" black box, 2. Quantitative model for interpreting foraminiferal carbon isotope data. Paleoceanography 6: 639-655

Spero HJ, Parker SL (1985) Photosynthesis in the symbiotic planktonic foraminifer Orbulina universa, and its potential contribution to oceanic primary productivity. J Foram Res 15(4): 273-281

Spero HJ, Williams DF (1988) Extracting environmental information from planktonic foraminiferal $\delta^{13} \mathrm{C}$ data. Nature 335(6192): 717-719

Spero HJ, Williams DF (1989) Opening the carbon isotope "vital effect" black box, 1. Seasonal temperatures in the euphotic zone. Paleoceanography 4(6): 593-601

Spindler M, Hemleben C (1980) Symbionts in planktonic foraminifera (protozoa). Endocytobiology, endosymbiosis and cell biology 1: 133-140

Spindler M, Hemleben C, Salomons JB, Smit LP (1984) Feeding behavior of some planktonic foraminifers in laboratory cultures. J Foram Res 14(4): 237-249

Swart PK (1983) Carbon and oxygen isotope fractionation in scleractinian corals: A review. Earth-Sci Rev 19(1): 51-80

Urey HC (1947) The thermodynamic properties of isotopic substances. J Chem Soc London: 562-581

Usdowski E, Hoefs J (1993) Oxygen isotope exchange between carbonic acid, bicarbonate, carbonate, and water; a re-examination of the data of McCrea (1950) and an expression for the overall partitioning of oxygen isotopes between the carbonate species and water. Geochim Cosmochim Acta 57(15): 3815-3818

Usdowski E, Michaelis J, Böttcher ME, Hoefs J (1991) Factors for the oxygen isotope equilibrium fractionation between aqueous $\mathrm{CO}_{2}$, carbonic acid, bicarbonate, carbonate and water $\left(19^{\circ} \mathrm{C}\right)$. Z Phys Chem 170: 237-249
Vergnaud-Grazzini C (1976) Non-equilibrium isotopic compositions of shells of planktonic foraminifera in the mediterranean sea. Palaeogeogr Palaeoclimatol Palaeoecol 20(4): 263-276

Weber JN, Woodhead PMJ (1970) Carbon and oxygen isotope fractionation in the skeletal carbonate of reef building corals. Chem Geol 6: 93-123

Wefer G, Berger WH (1991) Isotope paleontology: growth and composition of extant calcareous species. Mar Geol 100: 207-248

Weger HG, Herzig R, Falkowski PG, Turpin DH (1989) Respiratory losses in the light in a marine diatom: Measurements by short-term mass spectrometry. Limnol Oceanogr 34(7): 1153-1161

Williams DF, Bé AWH, Fairbanks RG (1979) Seasonal oxygen isotopic variations in living planktonic foraminifera off Bermuda. Science 206(4417): 447-449

Williams DF, Bé AWH, Fairbanks RG (1981a) Seasonal stable isotopic variations in living planktonic from Bermuda plankton tows. Palaeogeogr Palaeoclimatol Palaeoecol 33(1-3): 71-102

Williams DF, Röttger R, Schmaljohann R, Keigwin LD (1981b) Oxygen and carbon isotopic fractionation and algal symbiosis in the benthic foraminifera Heterostegina depressa. Palaeogeogr Palaeoclimatol Palaeoecol 33(1-3): 231-252

Wolf-Gladrow DA, Bijma J, Zeebe RE (1999) Model simulation of the carbonate system in the microenvironment of symbiont bearing foraminifera. Mar Chem 64: 181-198

Zahn R, Mix AC (1991) Benthic foraminiferal $\delta^{18} \mathrm{O}$ in the ocean's temperature-salinity-density field: constraints on ice age thermohaline circulation. Paleoceanography 6(1): 1-20

Zeebe RE, Bijma J, Wolf-Gladrow DA(1999)A diffusionreaction model of carbon isotope fractionation in foraminifera. Mar Chem 64: 199-227

Zhang J, Quay PD, Wilbur DO (1995) Carbon isotope fractionation during gas-water exchange and dissolution of $\mathrm{CO}_{2}$. Geochim Cosmochim Acta 59(1): $107-114$

Zimmermann MA, Williams DF, Röttger R (1983) Symbiont-influenced isotopic disequilibrum in Heterostegina depressa. J Foram Res 13(2): 115-121 